\title{
HATE CRIMES IN INDIA: AN ECONOMIC ANALYSIS OF VIOLENCE AND ATROCITIES AGAINST SCHEDULED CASTES AND SCHEDULED TRIBES
}

\author{
SMRITI SHARMA \\ Email: smriti@econdse.org \\ Department of Economics \\ Delhi School of Economics
}

Working Paper No. 213

Centre for Development Economics

Department of Economics, Delhi School of Economics 


\title{
Hate Crimes in India: An Economic Analysis of Violence and Atrocities against Scheduled Castes and Scheduled Tribes
}

\author{
Smriti Sharma* \\ Department of Economics, Delhi School of Economics
}

December, 2013

\begin{abstract}
Crimes against the historically marginalized Scheduled Castes and Scheduled Tribes (SC/ST) by the upper castes in India represent an extreme form of prejudice and discrimination. In this paper, we investigate the effect of changes in relative material standards of living between the SC/STs and upper castes - as measured by the ratio of consumption expenditures of SC/STs to that of upper castes on changes in the incidence of crimes against SC/STs. Based on the hierarchical social structure implied by the caste system, we posit that an improvement in the economic position of lower castes relative to the upper castes is positively correlated with the incidence of crimes committed by the upper castes against the lower castes. Using official district level crime data for the period 2001-10, we find a positive association between crimes and expenditure of SC/ST vis-à-vis the upper castes such that a widening of the economic gap between groups is associated with a decrease in caste-based crimes. Moreover, this effect is driven by changes in the upper castes' economic well-being rather than changes in the economic position of the lower castes and tribes.
\end{abstract}

JEL classification: J15, K42

Keywords: Hate Crimes, Castes, India

*Email: smriti@econdse.org. Address for correspondence: Department of Economics, Delhi School of Economics, University of Delhi, Delhi-110007. I am grateful to my advisors Ashwini Deshpande and Parikshit Ghosh for their excellent guidance. Thanks are also due to Deepti Goel, Jeffrey Nugent, J.V. Meenakshi, Abhiroop Mukhopadhyay, Jared Rubin, Saurabh Singhal, Willa Friedman and participants at the PacDev 2013, IRES 2012 Workshop, ISNIE 2012, WEAI 2012, Delhi School of Economics, Indian Statistical Institute and Jawaharlal Nehru University for their comments, and to officials at the National Crimes Records Bureau for providing the data and clarifying my queries. All remaining errors are mine. 


\section{Introduction}

In India, ex-untouchable castes and several tribal groups continue to be subjected to discrimination, economic and social exclusion and a stigmatized identity (e.g. Thorat 1979; Deshpande 2011; Navsarjan Trust 2010). Additionally, similar to hate crimes in other parts of the world, these groups have been victims of bias-motivated crimes and atrocities at the hands of the upper castes. Atrocities against lower castes routinely take the form of rape of women, abuse by police personnel, harassment of lower caste village council heads, illegal land encroachments, forced evictions and so on (Human Rights Watch, 1999). These instances are in blatant violation of the Indian constitution that abolished untouchability and upholds the ideal of equality among all citizens. Subsequently, there have been other provisions such as the Scheduled Castes and Scheduled Tribes (Prevention of Atrocities) Act, 1989, which specifically target such hate crimes. In 2006, acknowledging the gravity of the problem, Indian Prime Minister Manmohan Singh equated the practice of untouchability to that of apartheid 1

In this paper, we analyze crimes against the historically disadvantaged Scheduled Castes and Scheduled Tribes (ex-untouchables and marginalized tribes, SCs and STs respectively) by the upper castes to understand the mechanisms that cause crimes based on group identity to occur repeatedly. The objective of this study is to analyze whether regional variations in the incidence of violence by the upper castes against the lower castes are systematically linked to variations in relative group economic outcomes of lower castes and tribes and upper castes. Based on the hierarchical social structure implied by the caste system such that the upper castes have traditionally been economically better-off than the lower castes with resulting social dominance, we posit that an improvement in the economic position of lower castes relative to the upper castes is positively correlated with the incidence of crimes committed by the upper castes against the lower castes.

Theoretically, an improvement in the relative economic status of SCs and STs as compared to upper castes could lead to either a decrease or an increase in the incidence of caste-based crimes. It could lead to a decrease in caste-based crimes on account of various factors. One, an improvement in the relative economic position of lower castes could result in an increased ability to defend themselves against physical harm by the upper castes by investing in better security measures. Two, it could lend them greater confidence to report crimes to the police which could lead to a reduction in future crimes ${ }^{2}$

\footnotetext{
${ }^{1}$ Rahman, M. "Indian Leader Likens Caste System to Apartheid Regime". The Guardian, Dec. 28, 2006.

${ }^{2}$ Iyer et al. (2012) find that the political empowerment of women by way of higher mandated representation at local government levels induces strong positive and significant effects on reporting of crimes by women.
} 
Three, an improvement in their bargaining power could lead to the upper castes having greater respect for the low castes. On the other hand, the economic empowerment of historically marginalized SCs and STs could increase the incidence of caste-based crimes in the following ways: one, they could be perceived as more attractive targets for violence especially where the motivation is to extract some form of economic surplus; two, they may be perceived as a threat to the established social, economic and political position of the upper castes. This could lead to greater incidence of crimes against lower castes by the upper castes as a means of asserting their superiority and expressing their frustration at the shift in status quo. Therefore, which of these effects dominate constitutes an interesting empirical question.

While there is literature from India exploring the relationship between murders and female-male ratios (Dreze and Khera, 2000), crime and inequality (Sharma, 2011), effect of economic reforms on murders (Prasad, 2012), natural disasters and crime (Roy, 2010), effect of female political representation on crimes against women (Iyer et al., 2012) and the effect of rainfall shocks on domestic violence and dowry deaths (Sekhri and Storeygard, 2013), crimes against SCs and STs remain under-researched. This paper is among the first to analyze data on crimes committed against SCs and STs. This is largely facilitated by the fact that starting 2001, official data on such crimes became available at the level of the district. To the best of my knowledge, the only other existing piece of research studying crimes against SC/ST groups is Bros and Couttenier (2012). Using cross-sectional district-level crime data for 2001, they find crimes against SC/ST groups to be higher in districts that have greater commonality of water sources. Common water sources imply water sharing between castes which is considered ritually polluting for the upper castes- more so in rural areas- and is often countered with acts of violence against the lower castes $3^{3}$ Our study investigates a different hypothesis and exploits the panel structure of the data through which fixed unobservable factors can be controlled.

Our paper can be considered closest in terms of motivation to Mitra and Ray (2013) inasmuch as they too consider the relationship between group-wise economic progress and inter-group conflict. Using Hindu-Muslim riots data for India, they find that an improvement in Muslims' well-being leads to an increase in Hindu-Muslim riots while Hindus' well-being has no significant effect. However, there are two crucial differences between the two studies. Firstly, they analyze communal riots, which represent violence involving a large group of people, while we study individually targeted caste-based violence.

\footnotetext{
${ }^{3}$ The Economic and Political Weekly regularly features incident reports about caste-based violence. A common theme in all such reports is that the source of aggression lies in the fact that lower castes frequently access sites such as tea stalls, cinema halls, places of worship and other common spaces that were earlier the domain of only the dominant castes. Please see Section 5 for some such references.
} 
Secondly, and more importantly, their data do not allow separation of perpetrators and victims by religion, except by inference, whereas in our data, the identification between victims $(\mathrm{SC} / \mathrm{ST}$ ) and offenders (non-SC/ST) is clear from the start. Thus, our study is a new contribution to the discussion of group-based violence in the Indian context. However, there is an extensive social science literature from the United States that has studied racial violence and this paper builds on that literature.

Using district level official data on crimes against SCs/STs and per capita expenditures as a proxy for material standard of living, we find that the incidence of caste violence is positively correlated with the ratio of expenditures of lower castes and tribes to that of upper castes. Dividing the crimes into predominantly violent crimes and non-violent crimes, we find that changes in relative material standards of living between groups lead to changes in violent crimes aimed at extracting some form of economic surplus or property from the victims. Moreover, this effect is driven by changes in the upper castes' economic well-being rather than changes in the economic position of the lower castes and tribes.

Although discrimination has largely been discussed in the context of labour markets and access to public goods, this is among the first studies to quantitatively analyze the phenomenon of crimes targeted at the SC/ST groups. Since crimes committed by individuals belonging to non-scheduled groups against SC/ST individuals fall under the broad category of hate crimes, this paper will be nested in that literature while also drawing from the general crime literature.

The remainder of this paper is organized as follows. Section 2 provides a background of the existing inequalities on account of the caste system and a review of the hate crimes literature. Section 3 describes the dataset, summary statistics and the empirical framework. Section 4 presents the results and Section 5 discusses and concludes.

\section{Related Literature}

\subsection{The Indian Caste System}

The 'caste system' is an arrangement of the Hindu population into several thousand groups called 'jatis' (castes). These groups have emerged from the ancient varna system (also translated as caste) according to which society was divided into initially four, later five, hereditary, endogamous, mutually exclusive and occupation-specific groups. At the top of the varna system were the 'Brahmins' (priests and teachers) and the 'Kshatriyas' (warriors and royalty), followed by 'Vaishyas' (traders, merchants and moneylenders) and finally the 'Shudras' (engaged in menial labour and low-end jobs). Over time, the Shudras 
split into two tiers, with those engaged in the most menial and dirty jobs being called the 'Ati-Shudras'. The Ati-Shudras were considered untouchable, such that any contact with them was seen as polluting. They were forced to live in segregated housing, denied access to schools and places of worship attended by upper castes, and required to maintain physical distance from upper castes in order to not pollute them. Additionally, there are the indigenous tribes (or the Adivasis) who on account of geographical isolation, primitive agricultural practices and distinct lifestyle and customs have been socially distanced and face large-scale exclusion from mainstream Indian society $\left.\right|^{4}$

In 1950, the Constitution notified the untouchable jatis and the Adivasis as 'Scheduled Castes' and 'Scheduled Tribes' respectively, in order to remedy their extreme social, educational and economic backwardness 5 Affirmative action was extended to them in the form of reservations or quotas. This amounts to 22.5 percent of seats in national and state legislatures, village panchayats, institutions of higher education and 22.5 percent of government jobs being reserved for them. In addition to the SCs and STs, there is a third category known as the 'Other Backward Classes' (OBC) to which reservations have been extended since the early 1990s..$^{6}$ This group, while not burdened with the stigma of untouchability, were socially and educationally backward and suffered from a persistent lack of opportunity and poor socio-economic outcomes 7

Affirmative action has made a discernible positive impact in some dimensions. Political reservations at the state and national level legislatures have been a crucial instrument in elevating individuals belonging to $\mathrm{SC}$ and $\mathrm{ST}$ groups to positions where they exercise influence over policy decisions (Pande, 2003). Borooah et al. (2005) find that job reservations succeeded in increasing representation of SCs/STs in regular salaried employment by 5 percentage points compared to what it would have been otherwise.

However, gaps remain between the SC/ST and non-SC/ST groups. Empirical studies continue to find evidence of caste-based discrimination in labour markets and 'pre-market' discrimination in terms of access to public goods. ${ }^{8}$ Shah et al. (2006) in a survey of 565

\footnotetext{
${ }^{4}$ See Nathan and Xaxa (2012) for discussions on facets of exclusion and disadvantageous inclusion of Adivasis.

${ }^{5}$ While 'Scheduled Castes' is the official nomenclature, ex-untouchables prefer to self-identify themselves as 'Dalit' (meaning the oppressed) as a term of pride. We will use both terms depending on the context.

${ }^{6}$ Starting late 1990s, large-scale datasets such as National Sample Survey and National Family and Health Survey use four social group categories: SC, ST, OBC and 'Others'. 'Others' is a reasonable approximation of the upper caste category.

${ }^{7}$ Deshpande and Ramachandran (2013) find clear inter-group disparities in indicators such as consumption expenditures, wages and educational attainment with Others ranking the highest, followed by OBCs, and SCSTs at the bottom. However, among younger cohorts, they find convergence between OBCs and Others in terms of completion of lower education levels and access to white-collar jobs.

${ }^{8}$ For detailed discussions on economic discrimination in India, see Deshpande (2011) and Thorat and
} 
villages across 11 large states in 2001-02 document the widespread practice of untouchability in a significant proportion of villages in the form of denial of entry to Dalits into non-Dalit homes and places of worship, blocking access to common water sources, separate seating for Dalit students in schools etc. Moreover, there is a burden of a 'stigmatized ethnic identity' (Berreman, 1971) that even richer Dalits continue to live with. The following account by a Dalit surgeon effectively summarizes the sentiment behind 'stigmatized ethnic identity': "I am a micro-surgeon specializing in hand and spinal reconstruction, and am [a Member of Legislative Assembly] from Bihar, but I still remain very much a dalit- a dhobi, to be precise- open to routine humiliation from the upper castes." 9 This stresses the fact that despite significant policy initiatives, notions about caste rigidities are deeply ingrained and upward economic mobility has not necessarily ensured social integration and tolerance. Violence against lower castes is only the most severe manifestation of that intolerance.

\subsection{Hate Crimes}

The term hate crime refers to "unlawful, violent, destructive, or threatening conduct in which the perpetrator is motivated by prejudice toward the victim's putative social group" (Green et al., 2001, p.480). The most crucial element that differentiates hate crimes from similar non-hate crimes is the underlying motivation. Hate crimes are characterized by a deliberate intention to victimize an individual because of his membership in a certain social group. A review of the literature, most of which comes from the United States and Europe, indicates that among other things, relative economic position of the dominant group vis-à-vis the subaltern group is an important determinant of hate crimes. Disciplines in the social sciences offer distinctive theories explaining hate crimes and this section summarizes the theoretical and empirical evidence.

Gale et al. (2002) reason that since hate crimes are motivated by a desire to make the victim worse off (even though that may happen at a cost to the perpetrator), they can model it as a function of ill will on the part of the perpetrator with respect to the victim. They extend Becker's (1981) model of envy and altruism to explain the incidence of hate crimes. While altruism implies that one's utility function depends positively on the well-being of another, envy implies the opposite such that one's utility function depends negatively on the well-being of those one is envious of. Because relative status matters in Becker's framework, it is plausible that if the income gap between the minority and dominant group reduces, this could provoke envious members of the dominant group to

Newman (2010).

${ }^{9}$ Kanaujia, R.R. "Surgeon Second, Dhobi First". Tehelka, February 3, 2007 
resort to violence as a way to reduce the well-being of minority members. Using American state-level data for 1992-1995, they find the ratio of black income to white income to have a positive association with hate crimes.

Mitra and Ray (2013) develop a theoretical economic model to explain the incidence of ethnic conflict as a function of economic progress of two groups in society where members of either group can be aggressors or victims. However, their model does not explicitly take into account relative economic position of the two groups. They develop a model as follows from the perspective of both aggressors and victims: a potential aggressor must decide whether to let an encounter escalate to a situation of religious conflict. A potential victim, on the other hand, can defend himself using a variety of security measures. However, the victim's adoption of such measures depends on his economic status. Depending on the income levels, probability of attack, probability of success of the attack, cost of perpetrating violence, cost of protection and income loss on account of attacks, they develop protection functions and attack functions. Their main result states that economic improvements for a group will lead to greater violence perpetrated against that group if it is relatively poor and the greater the proportion of potential victims as compared to aggressors in the group. But if the group is relatively well-off, the effect of group income changes on violence is ambiguous. If the group is more likely to consist of aggressors rather than victims, then economic improvement for the group will lead to a decline in violence instigated by that group on members of the other group. The empirical exercise using data on Hindu-Muslim riots from India that follows the theoretical model shows that Hindu per-capita expenditures have a negative effect on conflict while the coefficient on Muslim per-capita expenditures is significant and positive. They also cite ethnographic studies that corroborate their empirical findings.

While the papers by Gale et al. (2002) and Mitra and Ray (2013) use incomes and expenditures to measure some form of economic competition, papers from other social sciences measure competition- economic and political- in more general terms.

The frustration-aggression thesis of Dollard et al. (1939) and Hovland and Sears (1940) suggests that during periods of economic stress, there is an innate tendency to lash out against a vulnerable scapegoat, which is often an out-group that may be linked to the source of the stress. Pinderhughes (1993) documents attitudes of white hate crime offenders and find that they blame their economic insecurity on affirmative action policies that increase competition with minorities and immigrants.

Competition theory suggests that inter-group conflict is heightened when niches that the minority and dominant groups traditionally operated in start to overlap. Niches could be in the form of occupational sectors, residential patterns etc. Studies of riots and 
lynchings suggest that competition for jobs leads to greater inter-racial violence (Price et al. 2008; Beck and Tolnay 1990; Olzak 1990; Olzak et al. 1996). Bonacich (1972) explains ethnic antagonism by way of "split labour markets" where markets are split along ethnic lines such that there is a large differential between two groups in the price of labour for the same occupation. Employers use cheaper labour as a way to challenge the more organized, higher paid labour thereby leading to inter-group violence. Jacobs and Wood (1999) investigate the relationship between economic and political competition and inter-racial murders for 165 US cities. As economic competition for jobs increases between blacks and whites, murders of blacks by whites increase. Additionally, cities with a black mayor experience more murders of blacks by whites 10 Eitle et al. (2002) find that economic competition- measured by the ratio of white and black unemployment ratehas a positive effect on crimes committed by whites against blacks. On the other hand, political threat- ratio of black to white voters- has no significant effect on the interracial crimes.

The defended neighbourhoods view suggests that hate crimes are used as an exclusionary tactic for turf protection and to maintain the existing hierarchy in society. Many hate crimes result from dominant group concerns about minority group encroachment. Research by Lyons (2007) on Chicago neighborhoods and by Green et al. (1998) on New York communities indicates that racially motivated hate crimes are higher in traditionally white neighbourhoods experiencing an influx of minority population.

\section{$3 \quad$ Data and Methodology}

\subsection{Crime Data}

The crime data used in this paper are from the annual publication 'Crime in India' by National Crime Records Bureau (NCRB), Government of India. This data is based on complaints or 'first information reports' (FIR) filed with the police.11 While earlier years reported crimes at the state level, since 2001, data on crimes against SC/ST under various categories have also become available at the district level. The distinctive feature of this dataset is its classification system. The data are defined in a way such that the victim

\footnotetext{
${ }^{10}$ While dealing with discriminatory tendencies and not hate crimes formally, Becker (1957) finds that discrimination faced by older and more educated blacks is greater.

${ }^{11}$ A First Information Report (FIR) is a written document prepared by the police when they receive information about the commission of a 'cognizable' offence from either the victim or by someone on his behalf. As defined by the Code of Criminal Procedure of India, a 'cognizable' offence is one in which the police is empowered to register an FIR, investigate, and arrest an accused without a court-issued warrant. A 'non-cognizable' offence is an offence in which police cannot register an FIR, investigate or arrest without prior permission from the court. NCRB data records only cognizable offences.
} 
belongs to the SC/ST group and the offender to a non-SC/ST group. It should be noted at the outset that data are not collected for the following cases: (i) when the victim is non-SC/ST and offender is SC/ST; (ii) when both victim and offender are SCs/STs; and (iii) when both victim and offender are non-SCs/STs 12

For this study, we use the crime data from 2001 to 2010 for 415 districts that make up the following 18 large states: Haryana, Himachal Pradesh, Punjab, Uttar Pradesh, Uttarakhand, Karnataka, Andhra Pradesh, Kerala, Tamil Nadu, Bihar, Jharkhand, Orissa, West Bengal, Madhya Pradesh, Chhattisgarh, Gujarat, Rajasthan and Maharashtra.

There are two main types of crimes: those reported under the Indian Penal Code (IPC) and those that are registered under the Special and Local Laws (SLL). While the IPC category includes mostly violent crimes that affect the broader population in general, the SLL are enacted to counter other social practices prohibited by various laws. IPC crimes include: i) murder, ii) rape, iii) physical assault or hurt, iv) kidnapping, v) robbery, vi) arson, vii) dacoity ${ }^{13}$ and viii) other classified IPC crimes. Other classified IPC crimes constitutes a residual category that includes crimes such as assaulting public servants, killing cattle, criminal trespass and intimidation etc. Crimes under SLL are: i) Protection of Civil Rights Acts, 1955, and ii) The Scheduled Castes and Scheduled Tribes (Prevention of Atrocities) Act, 1989. These acts constitute special social enactments to safeguard the interests of SC/ST groups. Examples of crimes included under SLL are: denying admission to Dalits into places of recreation and worship, educational institutions and hospitals; denying Dalits access to water sources; wrongfully occupying land owned by SC/ST; stripping them naked; practice of untouchability; compelling them to do bonded labour or scavenging jobs and so on 14 The Prevention of Atrocities Act specifies provisions for rehabilitation and compensation of victims and setting up of special courts to expedite the trial of cases. Broadly, the IPC crimes include acts of overt force and aggression and are predominantly violent crimes. On the other hand, SLL crimes are untouchability related offences with the intention of humiliating members of the lower castes, with some amount of violence. Hence, they are largely non-violent crimes.

The issue of under-reporting of crime is a standard limitation of most official data on crime, even for developed countries. For a hate crime, under-reporting is expected for a host of reasons that include intimidation, fear of reprisals and a lack of confidence in the

\footnotetext{
${ }^{12}$ Data on crimes against SCs/STs, women and children are collected since these groups are considered vulnerable.

${ }^{13}$ When five or more persons conjointly commit or attempt to commit a robbery, or where the whole number of persons conjointly committing or attempting to commit a robbery, and persons present and aiding such commission or attempt, amount to five or more, every person so committing, attempting or aiding, is said to commit 'dacoity'.

${ }^{14}$ The complete list of SLL crimes against SC/ST is in Appendix A.
} 
criminal justice system to resolve the problem ${ }^{15}$ Moreover, a low caste victim is likely to feel ashamed in reporting a crime where he has been humiliated on account of his social identity. Ideally, one would like to use victimization surveys to study crimes of this nature. However, in the absence of such data, this paper makes use of the best available nationally representative data and we believe that is a good starting point, especially since quantitative evidence on crimes against SCs and STs is limited ${ }^{16}$ The district fixed effects in our regression are able to control for the district-specific time-invariant component of under-reporting.

\subsection{Explanatory Variables}

Since our unit of analysis is the district, district-level information on the explanatory variables is calculated from the large-scale household surveys conducted once in five years by the National Sample Survey Organization (NSSO). Since our crime data spans the period 2001-2010, we use NSS data from the 'Consumer Expenditure Survey' and 'Employment-Unemployment Survey' modules of 1999-2000 (55th round) and 2004-05 (61st round). Since there were changes in some district boundaries between the two rounds of NSS data, we make the districts comparable using the weights provided by Kumar and Somanathan (2009).

In order to utilize the entire time series of district-level crime data and also to match it with the two rounds of district-level data from NSS, for the first period, we aggregate crimes for years 2001 to 2005 and for the second period, we aggregate crimes for years 2006 to 2010. This aggregation also overcomes the problem of many districts reporting zero crimes in a single year. Therefore, we have a two period panel with 415 districts in each period.

The primary variable of interest is the material standard of living of SCs/STs relative to that of the upper castes. In order to capture standard of living, we use data on consumption expenditure from the NSS Consumer Expenditure Survey ${ }^{17}$ Thus, our principal variable is defined as the logarithm of ratio of SC/ST expenditure to upper caste

\footnotetext{
${ }^{15}$ Reports suggest that police officers are often unwilling to file complaints lodged by members of lower caste groups.

${ }^{16}$ The India Human Development Survey (IHDS) of 2005 asks households whether they have been victims of crimes such as theft, burglary, physical hurt or threats. However, there is no way of knowing if crimes against SCs/STs were committed by non-SC/STs. Prasad (2013) in a comparative analysis of the IHDS and NCRB data finds that while the NCRB data is under-reported, there is a positive and significant relationship between police-recorded and victim-reported crimes. This suggests that police data are indicative of actual crimes and can enable identification of high and low crime districts.

${ }^{17}$ Details on computation of real monthly per capita consumption expenditure are in Appendix B. 1999-2000 is used as base year.
} 
expenditure. Ideally, one would like to use some measure of income to study differences in standard of living but that is difficult to collect in a developing country like India. In developing countries, expenditure serves as a good proxy for income for several reasons. Firstly, at low levels of income, savings are negligible resulting in a close correspondence between income and consumption expenditure. Secondly, wage or earnings data, even when reliable, may not account for days of employment and seasonality of work. Moreover, wage or earnings data in the NSS is reported only for those who are employed in the regular salaried sector or as casual labour and not for those who are self-employed. However, wage data for casual workers are often missing or unreliable. Thirdly, payment is often in kind and wage data typically accounts for the monetary component of earnings. Finally, like in the case of agricultural households, a household is both a production and consumption unit and it is difficult to distinguish between receipts and outflows (Deaton, 1997) ${ }^{18}$

In addition to the above, we control for share of SCs/STs in the district population and its squared term. Becker (1957) suggests that the effect of the minority group size can go in either direction. An increase in numbers could reduce prejudice and hostility on account of greater interaction between dominant and minority groups or 'strength in numbers' could help minority groups to better protect themselves. On the other hand, an increase in minority group size could have an adverse effect by fuelling fears that the minority group is trying to challenge the dominant group (either through political mobilization or posing a competition for scare resources) ${ }^{19}$ District-level average per capita expenditure accounts for overall prosperity. Expenditure-based Gini coefficient accounts for overall inequality. We control for percentage of population living in rural areas since caste-based crimes are likely to be a predominantly rural phenomenon. Educational attainment is controlled for by introducing categorical variables for different levels of education: illiterate, primary, secondary, higher secondary and above. Unemployment is an important determinant of crime since unemployed people with no legal income are more likely to engage in illegal activities as a way of earning an income ${ }^{20}$ However, in developing countries, the underemployment rate is a more accurate measure of time utilization. Underemployment

\footnotetext{
${ }^{18}$ World Bank (2000) also summarizes the preference for consumption measures by arguing that "Consumption is conventionally viewed as the preferred welfare indicator, for practical reasons of reliability and because consumption is thought to better capture long-run welfare levels than current income." $(p .17)$

${ }^{19}$ Blumer (1958) posits that perceived threat among the dominant group manifests in the following ways: (i) a feeling of superiority; (ii) a feeling that the subordinate group is intrinsically different; (iii) a feeling of exclusive claim over certain privileges; and (iv) a fear that the subordinate group desires a greater share of the dominant group's prerogatives.

${ }^{20}$ Evidence on the relationship between unemployment rates and hate-motivated crimes is quite mixed. For example, Falk et al. (2011) find unemployment rates to positively affect violent and non-violent right wing extremist crimes in Germany. However, Krueger and Pischke (1997) find no relationship between incidence of anti-foreigner crimes and unemployment rate in post-unification Germany during 1991-93.
} 
is commonly defined as the underutilization of labour time or skills of the employed either due to seasonality of work or lack of sufficient work. ${ }^{21}$ Percentage of males in the 15-24 age groups in the population represents the size of the group that is most likely to engage in criminal activity.

We also control for political competition at the state-level by using effective number of parties (Laakso and Taagepara, 1979) that is calculated using data from the state assembly election reports from the Election Commission of India. ${ }_{22}^{22}$ The idea is that in the event of smaller number of parties competing, since a larger share of votes is required for the winning party, parties need to build broad alliances spanning all social groups and cannot explicitly cater to the interests of a particular group, while in case of a larger number of parties, since the required winning margin is smaller, parties rely on particular social groups for support. Based on this reasoning, we would expect states with greater electoral competition (larger effective number of parties) to be more sympathetic to the cause of the SC/ST groups thereby leading to lesser violence against them. Wilkinson (2004) finds that Indian states with higher effective number of parties experience fewer Hindu-Muslim riots.

\subsection{Summary Statistics}

Table 1 contains the summary statistics of the district-level data for each of the two periods separately as well as for the full data. Of the average 430 total crimes against SC/ST per district, approximately 288 are IPC crimes and 142 are SLL crimes. We define $\mathrm{SC} / \mathrm{ST}$ total crime rate as the number of total crimes against SC/ST per $100000 \mathrm{SC} / \mathrm{ST}$ population. IPC crime rate and SLL crime rate are similarly defined. The SC/ST total crime rate is 100 while the SC/ST IPC crime rate is 67 and SC/ST SLL crime rate is 33. Among the IPC crimes, we make a distinction between 'crimes against body' and 'non-body crimes'. Body crimes are the sum of murder, rape, kidnapping and physical assault/hurt. Non-body crimes are the sum of dacoity, robbery, arson and other classified IPC crimes. The SC/ST body crime rate is 23 and the non-body crime rate is 43 . The general crime rate which measures crimes where the victims are non-SC/ST- defined as total IPC crimes in the district less IPC crimes against SC/ST per 100000 non-SC/ST population- is 1544. On average, crime rates against SC/ST and general crime rates registered a decline between the first and second period.

In terms of broad state-level statistics, Rajasthan has the highest SC/ST total crime

\footnotetext{
${ }^{21}$ Details on calculation of underemployment and unemployment rates are in Appendix C.

${ }^{22}$ The formula for effective number of parties is $n=1 / \Sigma p_{i}^{2}$ where $p_{i}$ is the proportion of votes received by party $i$ in the state elections. Instead of using the total number of parties, this measure places greater weight on parties that have a higher share of votes as compared to those with a low vote share.
} 
rate averaged over the period (29.82). Other states with high SC/ST crime rates are Madhya Pradesh (25.83), Andhra Pradesh (23.25), Uttar Pradesh (16.57) and Bihar (16.26). The lowest crime rates are recorded in West Bengal (0.12) and Punjab (1.81). In terms of IPC crimes against SC/ST, Rajasthan (24.2), Madhya Pradesh (23.8) and Andhra Pradesh (14.21) have high crime rates whereas in terms of SLL crimes against SC/ST, Bihar (10.63), Karnataka (9.66) and Andhra Pradesh (9.04) are the states reporting high rates.

The district-level average real monthly per capita expenditure is Rs. 535 and the expenditure-based Gini is 0.25. The SC/ST average real expenditure is Rs. 433, while it is Rs. 679 and Rs. 523 for the upper castes and OBCs respectively. Between the two periods, all social groups witnessed an increase in per capita expenditures: SC/ST expenditures increased 19.6 percent, whereas expenditure of upper castes and OBCs grew 36.4 percent and 27.5 percent respectively, indicating that the rate of increase was slowest for the SC/ST groups. Therefore, this translates into a decline in the ratio of $\mathrm{SC} / \mathrm{ST}$ expenditure to upper castes' expenditure over the two periods from 71 percent to 64 percent.

$\mathrm{SC} / \mathrm{ST}$ account for 29 percent of the district-level population and 79 percent of the population is in rural areas. The underemployment rate is around 16 percent. Males in the 15-24 age groups make up 9 percent of the population. 46 percent of the population is illiterate, 20 percent have completed primary education, 24 percent have completed secondary education and only 10 percent has completed higher secondary and higher levels of education. The state-level effective number of parties is around 4.6.

\subsection{Empirical Specification}

Our main empirical specification uses a linear fixed effects regression model. The general form of the estimating equation is:

$$
y_{d t}=\alpha_{1}+\alpha_{2} e_{d t}+\Sigma_{k} \theta^{k} X_{d t}^{k}+\delta_{d}+\gamma_{t}+\epsilon_{d t}
$$

where the dependent variable $y_{d t}$ is the logarithm of the $\mathrm{SC} / \mathrm{ST}$ crime rate in district $d$ in time period $t$. Our primary variable of interest $e_{d t}$ is logarithm of the ratio of expenditure of SCs/STs to upper castes. $X_{d t}^{k}$ is the vector of $k$ controls in district $d$ at time $t$ which includes the following variables listed previously in the explanatory variables section: district MPCE, share of SCs/STs in the population and its squared term, share of the population residing in rural areas, Gini coefficient, underemployment rate, share of population in different education categories (illiterate, primary, secondary, with higher 
secondary and above being omitted group), share of young males in the population and effective number of parties. District fixed effects $\delta_{d}$ control for the time-invariant districtspecific under-reporting of crime, long-standing caste relations in the district etc. A time dummy $\gamma_{t}$ controls for factors that are common across districts but vary across time such as changes in national-level policies or changing national attitudes towards marginalized groups that might affect hate crimes. $\epsilon_{d t}$ is the error term. Standard errors are clustered at the district level to account for possible correlated shocks to district-level crimes over time. Based on the hierarchical nature of inter-caste relations discussed in Section 2.1, we expect the coefficient of the relative expenditure term, $\alpha_{2}$, to be positive.

An alternative specification uses group-wise expenditures instead of relative expenditures to determine which group's economic changes are driving this relationship:

$$
y_{d t}=\beta_{1}+\beta_{2} S C S T \exp +\beta_{3} O B C \exp +\beta_{4} U C \exp +\Sigma_{k} \mu^{k} X_{d t}^{k}+\omega_{d}+\eta_{t}+\varepsilon_{d t}
$$

where the dependent variable $y_{d t}$ is the logarithm of the SC/ST crime rate in district $d$ in time period $t$ and $\beta_{2}, \beta_{3}, \beta_{4}$ are the coefficients on logarithm of expenditure terms for each of the three broad social groups: SCs/STs, other backward classes (OBCs) and upper castes (UCs) respectively. Since we have group-wise expenditures, we do not control for overall expenditure. The other control variables, district fixed effects and time dummy are included the same way as in equation (1).

\section{Analysis}

\subsection{Regression Results}

Table 2 presents the main results. In column 1 , the dependent variable is the $\mathrm{SC} / \mathrm{ST}$ total crime rate. We use the following explanatory variables: share of SCs/STs in the population and its squared term, share of population living in rural areas, Gini coefficient, underemployment rate, categorical variables for each of the education levels, share of young males and effective number of parties. The coefficient of the relative expenditure term is positive and significant. Since crime rates and relative expenditures show a downward trend between the two periods over which we analyze the data, this implies that a 1 percent decrease in the relative expenditures or widening of the gap between lower and upper castes is associated with a 0.3 percent decrease in violence. This translates into a decrease of 3 crimes per $100000 \mathrm{SCs} / \mathrm{STs}$ for a 10 percent decrease in the ratio of SCST expenditures to upper caste expenditures. Share of SC/ST and its quadratic term are negative and positive respectively, suggesting that an increase in the share of 
SCs/STs is associated with a decrease in victimization and the decrease is slower as the share of SCs/STs increases. Across all regressions, we obtain similar results for the share of SCs/STs variable (convex relationship) 23

In column 2 of Table 2 , the dependent variable is the SC/ST IPC crime rate. We use the same explanatory variables as in column 1. Results are qualitatively similar to column 1. A 1 percent decrease in the relative expenditure is associated with a 0.35 percent decrease in IPC crimes- largely violent crimes- committed by the upper castes against the SC/ST groups. Overall higher inequality in the district, as measured by the Gini, is positively associated with IPC crime rates. This result is in accordance with other literature that finds inequality to be significant determinant of violent crimes in society (Kelly, 2000; Fajnzylber et al., 2002). In column 3 of Table 2, the dependent variable is the $\mathrm{SC} / \mathrm{ST} \mathrm{SLL}$ crime rate. In this regression, the relative expenditure term is insignificant thereby indicating that the relative economic position of SC/ST vis-àvis the upper castes is not associated with the SLL crime rate. The coefficient on the effective number of parties which was insignificant in columns 1 and 2 , is now negative and significant implying that as the number of parties competing in the state increases, SLL crimes against SC/ST register a decline.

To understand the effects of group-wise economic progress on the incidence of caste violence, in Table 3, instead of using relative expenditures, we enter the logarithm of group-wise expenditures: expenditure of SCs/STs, expenditure of other backward classes (OBCs) and the expenditure of upper castes (UCs). In column 1, the dependent variable is the $\mathrm{SC} / \mathrm{ST}$ total crime rate. While OBC expenditure and SC/ST expenditure have no significant association with crime rate, the upper castes' expenditure coefficient is negative and significant implying that a 1 percent increase in their expenditure is associated with a 0.34 percent decrease in crime rates. The most plausible mechanism at play is that of opportunity cost. This idea crucial to models of crime originating with Becker's influential work (1968) states that with an increase in the material standard of living, each unit of time spent in committing crimes becomes more costly for the perpetrators. As we show later, upper castes' expenditure has no effect on the incidence of general crimes implying that it is the lower castes that are differentially targeted with changes in the economic position of upper castes. Moreover, as our data indicate, the average expenditure increased most rapidly for the upper castes and slowest for the SC/ST groups, thereby increasing the gap between the two groups and diminishing the perceived threat associated with the economic position of the subordinate group relative to the dominant

\footnotetext{
${ }^{23}$ Krueger and Pischke (1997) find that the percentage of foreigners has no effect on anti-foreigner crimes in the western Germany but in eastern Germany, foreigner victimization rate falls as their relative number increases.
} 
group.

In column 2, the dependent variable is the SC/ST IPC crime rate. Again, while $\mathrm{SC} / \mathrm{ST}$ and $\mathrm{OBC}$ expenditure is insignificant, a 1 percent increase in upper castes' expenditure is associated with a 0.56 percent decrease in IPC crime rates. In column 3 , the dependent variable is the SC/ST SLL crime rate. All the group-wise expenditure terms are insignificant. The coefficient on the effective number of parties is negative and significant. As in the relative expenditure specification in of Table 2, the Gini coefficient is positively associated with IPC crime rate but uncorrelated with SLL crime rate.

Results from Table 2 and Table 3 jointly show that firstly, while relative expenditure is an important determinant of caste-based crimes, it is the perpetrator characteristics and not the victim characteristics driving the results. Secondly, while IPC crimes are correlated with relative expenditure and upper castes' expenditure, SLL crimes are not. This indicates that changes in relative economic status of groups are associated with changes in largely violent crimes rather than non-violent crimes. This seems to be consistent with findings from field surveys that report increases in violent acts by upper castes whenever lower castes try to assert their rights or demand their fair share by way of wages, forest rights or basic human rights. Non-violent SLL crimes that seek to insult and humiliate victims on account of their lower social status occur on a more routine basis as a result of long term social attitudes, for instance beliefs about hierarchy or the "right" order of the world, place of the Dalits in the social hierarchy and therefore, they might not be as closely related to changes in economic status.

In Table 4, we decompose the IPC crimes into two mutually exclusive categories: crimes against body and non-body crimes. Body crimes are the sum of murder, rape, kidnapping and physical assault/hurt. Non-body crimes are the sum of dacoity, robbery, arson and other classified IPC crimes and are largely property crimes. In columns 1 and 2, where the dependent variable is the SC/ST body crime rate, we report results of the relative expenditure specification and the group-wise expenditure specification respectively. Neither relative expenditure nor the upper castes' expenditure is associated with the incidence of body crimes. In columns 3 and 4 , the dependent variable is the $\mathrm{SC} / \mathrm{ST}$ non-body crime rate. Column 3 indicates a positive association between relative expenditure of SC/ST and upper castes and non-body crimes. In column 4, upper castes' expenditure is negatively associated with non-body victimization. The coefficient on the Gini is positive and significant for the non-body crimes but not for the body crimes. These results suggest that it is the non-body crimes component of the IPC crimes against $\mathrm{SC} / \mathrm{ST}$ that is responsive to changes in relative expenditure and upper castes' expenditure. This indicates that IPC crimes against SC/ST occur as crimes with the objective 
of expropriating or wresting economic surplus from the victims rather than inflicting physical bodily harm.

In Table 5, we add a control variable to capture how crime-prone the district is in general. While the relationship between hate crimes and non-hate motivated crimes has not been clearly established in the literature, it is plausible that areas with a culture of violence or higher level of general crimes are more susceptible to the occurrence of hate crimes on account of poorer law enforcement machinery. We measure how crime-prone a district is by constructing a variable called the 'general crime rate' that measures the general criminality in the district. It is calculated as total IPC crimes in the district less IPC crimes against SC/ST per 100000 non-SC/ST population. Since the NCRB does not have information on crimes against non-SCs/STs, this is a proxy variable that captures the same idea. In columns 1 and 2, the dependent variable is SC/ST total crime rate whereas in columns 3 and 4 , it is the SC/ST IPC crime rate ${ }^{24}$ Results from Table 2 and Table 3 are robust to controlling for general crimes rate. Moreover, in all specifications, we find that the coefficient on general crime rate is positive and significant suggesting that more crime-prone districts do in fact experience greater victimization of the $\mathrm{SC} / \mathrm{ST}$ community.

In Table 6.A and Table 6.B, we model the number of total crimes against SC/ST and IPC crimes against SC/ST respectively as count data and employ a negative binomial regression model. We add the logarithm of the SC/ST population on the right hand side. In column 1, the main explanatory variable of interest is the relative expenditure between SC/ST and upper castes, the coefficient of which is positive and significant. In column 3, we use the group-wise expenditures specification and find that the upper castes' expenditure is negatively associated with violence. In columns 2 and 4 , we also control for logarithm of general crime rate in the district and the results are qualitatively similar. Hence, our results are fairly robust to alterations in the estimation methodology.

\subsection{Some Further Questions}

This section discusses some questions and concerns that might follow from the results section and addresses how we mitigate these concerns. One of the concerns is that the crimes against SC/ST could be a part of the overall trend of general crimes in the district. The idea is that if the relative economic status of caste groups is also correlated with general crimes in the district, then we cannot conclude that it is only crimes against $\mathrm{SC} / \mathrm{ST}$ that are uniquely linked to relative group economic positions. In order to check

\footnotetext{
${ }^{24}$ Results from regressions where the dependent variable is the SC/ST SLL crime rate are similar to results in Tables 2 and 3.
} 
for this, in Table 7.A, we present results of regressions where the dependent variable is logarithm of general crime rate. If the coefficients on our expenditure variables turn out to be insignificant, we can rule out this concern. In column 1 , the coefficient of the relative expenditure term is insignificant, as are the group-wise expenditures in column 2 , which stress the fact that differences in material standard of living between caste groups uniquely affect crimes against SC/ST groups and are not associated with general crimes in society. As a robustness check, I model the general crimes as a count variable in Table 7.B and use the negative binomial regression model. Results are qualitatively similar to those in Table 7.A.

A second concern could be that our results are sensitive to particular variable definitions. In order to alleviate this concern, as can be seen in Table 8, we re-estimate the equations using alternative variable definitions as follows: (i) using the unemployment rate instead of the underemployment rate (block A); (ii) using the Theil Index instead of Gini as an inequality measure (block B) ${ }^{25}$ (iii) using seat share instead of vote share to calculate the effective number of parties (block C); (iv) measuring the dependent variable as crimes per 100000 total population instead of $100000 \mathrm{SC} / \mathrm{ST}$ population (block D) . Our results are robust to using these alternative measures of variables.

A third concern with the results could be that particular high crime states such as Rajasthan, Madhya Pradesh or Uttar Pradesh might be driving the results, such that excluding observations from those states might affect our results. In order to check for this, we iteratively run the entire set of regressions dropping one state at a time and find that our results are robust to such exclusions. Results using the SC/ST total crime rate as dependent variable are reported in Table 9 and Table 10 for the relative expenditure and group-wise expenditure specifications respectively. The bottom panels of Tables 9 and 10 show that our results hold even when we drop the high crime states of Rajasthan, Madhya Pradesh and Uttar Pradesh simultaneously.

A fourth concern is that of reverse causality. Targeted crimes of a violent nature against the SC/ST community could be a debilitating force leading to reduced earnings and expenditures, which would make them further worse-off compared to the upper castes. If this reverse causality exists, then our effects are overestimated and provide an upper bound of the true estimates.

A fifth possible concern could be out-migration of SCs and STs on account of such targeted violence from their districts to other lower crime districts ${ }^{26}$ In this case, our

\footnotetext{
${ }^{25}$ The formula for Theil Index is $\mathrm{T}=\Sigma_{p}\left\{(1 / n) *\left(y_{p} / \mu_{y}\right) * \ln \left(y_{p} / \mu_{y}\right)\right\}$ where $n$ is the number of individuals in the population, $y_{p}$ is the income of person $p$ and $\mu_{y}$ is the average income of the population.

${ }^{26}$ Tolnay and Beck (1992) find that southern counties in USA that witnessed high levels of lynching
} 
effects would be underestimated. While, we cannot control for this possibility in our regression analysis since the NSS data does not allow us to identify migration, we cite findings from other data sources to investigate this issue. Bhagat (2009) using 2001 Indian Census data documents that 62 percent of the internal migration in India is in the form of intra-district migration. Inter-district and inter-state migration account for 24 percent and 13 percent respectively of total internal migration. For males and females, employment and marriage respectively are the primary reasons for migration indicating that migration is on account of reasons other than violence. More crucially, since our unit of analysis is the district and the largest stream of migration is intra-district, our results are not likely to be affected.

Sixth, one can claim that the effects we observe are really those of changes in reporting of crimes rather than changes in actual incidence of crime. We argue that is not the case. Firstly, reporting is expected to a function of victim characteristics but what is explaining the crime rate in our results are not victim but perpetrator characteristics (Table 3). This gives us good reason to believe that what we are observing is a case of incidence rather than reporting of crime. A second and more minor point is that the SLL crimes are castebased crimes motivated solely by the lower caste status of the victims. Also, SLL crimes result in more serious penalties and punishments for perpetrators. Therefore, this should be the category that is most likely to be sensitive to reporting by victims ${ }^{27}$ However, as our regressions indicate, SLL crimes are not associated with changes in relative economic positions.

Finally, and more in the nature of a caveat, is the fact that since the analysis is conducted at the level of the district, nothing can be definitively said about the nature of individual motivations that leads to the incidence of such crimes. This means that theories that make predictions about individual incentives to engage in such behaviour that do not vary across districts, cannot be tested. Having said that, with the available data, these results provide evidence that variations in relative group economic positions are linked to variations in violence levels.

\section{Discussion and Conclusion}

This paper provides one of the first analyses of crimes against Scheduled Castes and Tribes in India with a view to understanding the effect of a change in the gap between

and mob violence against blacks during 1910-30 experienced greater levels of black out-migration as compared to other counties.

${ }^{27}$ Iyer et al. (2012) find better reporting of SLL crimes after lower castes obtain mandated representation in local councils. 
upper and lower castes' standard of living on the victimization of the SC/ST community. We find that changes in relative economic position between the lower castes and upper castes are positively correlated with changes in the incidence of hate crimes, such that a widening of the gap in expenditures between the lower and upper castes is associated with a decrease in crimes committed by the upper castes against the SCs/STs. Further, between the IPC and SLL crimes it is the violent IPC crimes that are responsive to changes in economic gaps. Moreover, this is driven by an improvement in the economic well-being of the upper castes rather than a decline in the economic position of the lower castes. We interpret this as the upper castes responding to changes in threat perception created by changes in the relative positions between the two groups. As a re-affirmation of this conjecture, we find that among the largely violent crimes, it is the non-body crimescrimes that seek to deprive the victim of his property symbolic of his material progressthat are affected by the changes in relative standards of living.

Although the incidence of such crimes is usually treated as a law and order problem by the system, it is more broadly a question of social justice. There is ample evidence that suggests that upper castes use and justify various forms of violence as tools to ensure adherence to caste-based norms and traditions by the lower castes. Attacks often take the form of collective punishment, whereby entire communities are punished for the perceived transgressions of individuals who seek to alter established norms or demand their rights. Dalits are attacked so that they can be taught a "lesson" for aspiring to higher standards by being more educated, acquiring more wealth and indulging in more conspicuous consumption 28 Inter-caste marriages where a Dalit boy marries a higher caste girl have resulted in looting and torching of Dalit villages in Dharmapuri district in Tamil Nadu (Senthalir, 2012) and ransacking and destruction of villages in Pabnava, Haryana (Katulkar, 2013). Dalit women, occupying the bottom of both the caste and gender hierarchies, are uniquely susceptible to violence. A 1997 report by the National Commission of Scheduled Castes and Scheduled Tribes succinctly states "Whenever Dalits have tried to organize themselves or assert their rights, there has been a backlash from the feudal lords resulting in mass killings, gang rapes, looting of Dalit villages" (p.2). Even though the magnitudes of the effects we obtain are small, a regular occurrence of such crimes instills a sense of apprehension and has a capacity for secondary victimization i.e., it creates a sense of vulnerability and anxiety not just for the victim but also for the wider community (McDevitt et al., 2001). ${ }^{29}$ Repeated incidents of individual-level hate

\footnotetext{
${ }^{28}$ See http://www.anti-caste.org/atrocities/. This website is a repository of articles on caste atrocities from various newspapers.

${ }^{29} \mathrm{McD}$ evitt et al. (2001) finds that victims of hate crimes experienced greater psychological harm and a sense of insecurity as compared to victims of similar non-bias-motivated crimes. Levin and McDevitt (1993) also argue that hate crimes have a more deleterious effect since victims of such crimes are 'inter-
} 
crimes may exacerbate existing tensions between groups and could escalate to situations of group-level conflict (Levin and Rabrenovic, 2001). This suggests that even though affirmative action has led to visible changes in some dimensions of economic conditions of SC/ST groups, they have not been truly empowered since notions of caste hierarchies remain deeply entrenched in society.

The working of the criminal justice system only perpetuates the problem. There is flagrant violation of justice in the form of police resistance in filing complaints; low conviction rates leading to easy acquittals for perpetrators; high pendency due to only a few special courts operating; and poor implementation of economic relief to victims. Newspaper reports frequently find that judgment on cases is delayed by several years due to the lax performance of the courts and the apathetic attitude of the legal machinery. A report discussing the performance of the SC/ST Prevention of Atrocities Act, 1989 finds that at the end of 2007, 79 percent of cases remained pending for trial at criminal courts showing no significant improvement over a pendency rate of 82.5 percent in 2001 (National Coalition for Strengthening SCs and STs PoA Act, 2010). Moreover, the pendency rate is approximately the same for all crimes under the Prevention of Atrocities Act, 1989, Protection of Civil Rights Act and IPC, indicating that the provision for speedy trials under Prevention of Atrocities Act, 1989 is not being duly followed. Such failures in investigating, filing and pursuing cases involving crimes against SC/ST groups empower potential perpetrators by signaling that crimes against lower castes will go unpunished and also further disempowers marginalized communities by eroding their trust in the legal system.

While our analysis uses the lowest level of disaggregated official data that are available, which is a good starting point, a study at the village level would make the analysis much richer since the occurrence of such events is highly dependent on dynamics at more local levels that we cannot observe in our data. Future research can aim to do the following: one, study the occurrence of such violence and atrocities through victimization surveys in order to better understand individual motivations; two, exploit overlaps in caste and religion identities to study the incidence of crimes; three, use newspaper reports to construct measures of crime incidence since this allows identification of crimes where both victims and perpetrators are non-SCs/STs or SCs/STs or perpetrators are SCs/STs and victims are non-SCs/STs. As was mentioned earlier, the police collects data on crimes by non-SCs/STs against SCs/STs since these are groups are considered vulnerable and figure prominently in public policy. But it would be interesting to study other classifications

changeable' i.e they are singled out on the basis of their social identity and not out of any prior personal vendetta. 
as well since this might allow us to identify for instance, the extent of retaliation, if any, by the lower castes and tribes. Also, since SCs/STs are a heterogeneous group- although constitutionally they are all given the same status- it would be interesting to measure conflict among various sub-castes on account of some sub-castes progressing politically or economically more than others. 


\section{References}

Beck, E.M., and Tolnay, S. (1990). The killing fields of the Deep South: The market for cotton and the lynching of blacks, 1882-1930. American Sociological Review, 55, 526-539.

Becker, G. (1957). The Economics of Discrimination. Chicago: University of Chicago Press

Becker, G. (1968). Crime and punishment: an economic approach. Journal of Political Economy, 76(2), 169-217

Becker, G., (1981). A Treatise on the Family, Cambridge, MA: Harvard University Press

Berreman, G. (1971). Self, situation and escape from Stigmatized Ethnic Identity, available at http://www.eric.ed.gov/PDFS/ED058344.pdf (accessed June 5, 2010)

Bhagat, R.B. (2009). Internal migration in India: Are the underclass more mobile? Available at http://iussp2009.princeton.edu/download.aspx?submissionId=90927 (accessed November 20, 2011)

Blumer, H. (1958). Race prejudice as a sense of group position. Pacific Sociological Review, 1(1), 3-7

Bonacich, E. (1972). A theory of ethnic antagonism: The split labor market. American Sociological Review, 37(5), 547-559.

Borooah, V. K., Dubey, A. and Iyer, S. (2007). The effectiveness of jobs reservation: Caste, religion and economic status in India. Development and Change, 38, 423-445.

Bros, C., and Couttenier, M. (2012). Untouchability and public infrastructure. Working Paper

Deaton, A. (1997). The Analysis of Household Surveys: A Micro-econometric Approach to Development Policy. Baltimore and London: Johns Hopkins University Press

Deshpande, A. (2011). The Grammar of Caste: Economic Discrimination in Contemporary India. New Delhi: Oxford University Press

Deshpande, A., and Ramachandran, R. (2013). How Backward are the Other Backward Classes? Changing Contours of Caste Disadvantage in India. CDE-DSE working paper 233

Dreze, J., and Khera, R. (2000). Crime, gender and society in India: Insights from homicide data. Population and Development Review, 26(2), 335-352

Dollard, J., Doob, L., Miller, N., Mowrer, O., and Sears, R. (1939). Frustration and Aggression. New Haven, CT: Yale University Press. 
Eitle, D., D'Alessio, S.J., and Stolzenberg, L. (2002). Racial threat and social control: A test of the political, economic, and threat of black crime hypotheses. Social Forces, $81(2), 557-576$

Election Commission of India. Statistical Reports of Assembly Elections, multiple years.

Fajnzylber, P., Lederman, D., and Loayza, N. (2002). What causes violent crime? European Economic Review, 46(7), 1323-1357

Falk, A., Kuhn, A., and Zweimuller, J. (2011). Unemployment and right wing extremist crime. Scandinavian Journal of Economics, 113, 260-285

Gale, L., Heath, W.C., and Ressler, R. (2002). An economic analysis of hate crime. Eastern Economic Journal, 28(2), 203-216

Green, D., McFalls, L. and Smith, J. (2001). Hate crime: An emergent research agenda. Annual Review of Sociology, 27, 479-504

Green, D., Strolovitch, D., and Wong, J. (1998). Defended neighborhoods, integration, and racially motivated crime. American Journal of Sociology, 104, 372-403.

Hovland, C.I., and Sears, R.R. (1940). Minor studies of aggression: VI. Correlation of lynchings with economic indices. Journal of Psychology, 9, 301-10.

Human Rights Watch (1999). Broken People: Caste Violence against India's Untouchables. New York: Human Rights Watch

Iyer, L., Mani, A., Mishra, P., and Topalova, P. (2012). The power of political voice: Women's political representation and crime in India. American Economic Journal: Applied Economics, 4(4), 165-193

Jacobs, D., and Wood, K. (1999). Interracial conflict and interracial homicide: do political and economic rivalries explain white killings of blacks or black killings of whites? American Journal of Sociology, 105, 157-190

Kanaujia, R.R. (2007). Surgeon Second, Dhobi First. Tehelka, February 3.

Katulkar, R. (2013). Atrocities against Dalits: The Pabnava incident. Economic and Political Weekly. http://www.epw.in/web-exclusives/atrocities-against-dalits-pabnavaincident.html

Kelly, M. (2000). Inequality and crime. The Review of Economics and Statistics, $82(4), 530-539$

Krueger, A., and Pischke, J. (1997). A statistical analysis of crime against foreigners in unified Germany. Journal of Human Resources, 32(1), 182-209

Kumar, H., and Somanathan, R. (2009). Mapping Indian districts across census years, 1971 to 2001. Economic and Political Weekly, XLIV(41), 69-88 
Laakso, M., and Taagepara, R. (1979). Effective number of parties: A measure with application to West Europe. Comparative Political Studies, 12, 3-27

Levin, J., and McDevitt, J. (1993). Hate crimes: The rising tide of bigotry and bloodshed. New York: Plenum.

Levin, J. and Rabrenovic, G. (2001). Hate crimes and ethnic conflict: an introduction. American Behavioral Scientist, 45(4), 574-587

Lyons, C.J. (2007). Community (dis)organization and racially motivated crime. American Journal of Sociology, 113(3), 815-863.

McDevitt, J., Balboni, J., Garcia, L., and Gu, J. (2001). Consequences for victims: a comparison of bias- and non-bias-motivated assaults. American Behavioral Scientist, 45(4), 697-713.

Mitra, A., and Ray, D. (2013). Implications of an economic theory of conflict: HinduMuslim violence in India. NBER working paper 19090

Nathan, D., and Xaxa, V. (Eds.) (2012). Social Exclusion and Adverse Inclusion: Development and Deprivation of Adivasis in India. New Delhi: Oxford University Press

National Coalition for Strengthening SCs and STs (PoA) Act (2010). 20 years Scheduled Castes and Scheduled Tribes (Prevention of Atrocities) Act Report Card. New Delhi.

National Commission of Scheduled Castes and Scheduled Tribes (1997). Highlights of the Report of the National Commission of Scheduled Castes and Scheduled Tribes for the years 1994-95 and 1995-96. New Delhi: Government of India

National Crime Records Bureau, Crime in India, Government of India, multiple years

National Sample Survey Organization, Employment-Unemployment Survey and Consumer Expenditure Survey, multiple years

Navsarjan Trust (2010). Understanding untouchability: A comprehensive study of practices and conditions in 1589 villages.

Olzak, S. (1990). The political context of competition: lynching and urban racial violence, 1882-1914. Social Forces, 69, 395-421

Olzak, S., Shanahan, S., and McEneaney, E.H. (1996). Poverty, segregation, and race riots: 1960 to 1993. American Sociological Review, 58, 590-613.

Pande, R. (2003). Can mandated political representation provide disadvantaged minorities policy influence? Theory and evidence from India. American Economic Review, 93 (4), 1132-1151.

Pinderhughes, H. (1993). The anatomy of racially motivated violence in New York City: a case study of youth in Southern Brooklyn. Social Problems, 40(4), 478-492. 
Prasad, K. (2012). Economic liberalization and violent crime. Journal of Law and Economics, 55, 925-948

Prasad, K. (2013). A comparison of victim-reported and police-recorded crime in India. Economic and Political Weekly, XLVIII(33), 47-53

Price, G.N, Darity Jr., W.A., and Headen Jr., A.A. (2008). Does the stigma of slavery explain the maltreatment of blacks by whites? The case of lynchings. Journal of Socio-Economics, 37(1), 167-193

Rahman, M. (2006). Indian Leader Likens Caste System to Apartheid Regime. The Guardian, December 28. http://www.guardian.co.uk/world/2006/dec/28/india.mainsection (accessed January 5, 2012)

Roy. S. (2010). The impact of natural disasters on violent crime. Working paper

Sekhri, S., and Storeygard, A. (2013). Dowry deaths: Consumption smoothing in response to climate variability in India. Working Paper

Sen, A., and Himanshu (2004). Poverty and inequality in India-I. Economic and Political Weekly, XXXIX(38), 4247-4263

Senthalir, S. (2012). Caste fire in Dharmapuri, Tamil Nadu. Economic and Political Weekly, XLVII (52), 12-13

Shah, G., Mandar, H., Thorat, S., Deshpande, S., and Baviskar, A. (2006). Untouchability in Rural India. Sage Publications: New Delhi

Sharma, G. (2011). Crime and inequality in India. Working Paper, University of Missouri.

Thorat, S. (1979). Passage to Adulthood: Perceptions from Below. In Sudhir Kakar, (ed.), Identity and Adulthood, New Delhi: Oxford University Press.

Thorat, S., and Newman, K. (Eds.) (2010). Blocked by Caste: Economic Discrimination in Modern India. New Delhi: Oxford University Press.

Tolnay, S., and Beck, E.M. (1992). Racial violence and black migration in the American south, 1910 to 1930. American Sociological Review, 57(1), 103-116

Wilkinson, S. (2004). Votes and Violence: Electoral Competition and Ethnic Riots in India. Cambridge: Cambridge University Press.

World Bank (2000). World Development Report 2000/01:Attacking Poverty. The World Bank: Washington D.C 
Table 1: Summary Statistics

\begin{tabular}{|c|c|c|c|c|c|c|}
\hline Variable & $\begin{array}{c}\text { Both periods } \\
\text { Mean }\end{array}$ & Std Dev & $\begin{array}{c}\text { Period } 1 \\
\text { Mean }\end{array}$ & Std Dev & $\begin{array}{c}\text { Period } 2 \\
\text { Mean }\end{array}$ & Std Dev \\
\hline \multicolumn{7}{|l|}{ Crime Incidence: } \\
\hline $\begin{array}{l}\text { Total Crimes against SC/ST } \\
\text { IPC crimes against SC/ST } \\
\text { SLL crimes against SC/ST } \\
\text { IPC body crimes against SC/ST } \\
\text { IPC non-body crimes against SC/ST } \\
\text { General IPC crimes }\end{array}$ & $\begin{array}{c}430 \\
288 \\
142 \\
95 \\
193 \\
21033\end{array}$ & $\begin{array}{l}(419) \\
(351) \\
(176) \\
(113) \\
(281) \\
(20059)\end{array}$ & $\begin{array}{c}418 \\
275 \\
144 \\
93 \\
182 \\
19503\end{array}$ & $\begin{array}{c}(435) \\
(351) \\
(174) \\
(112) \\
(272) \\
(18370)\end{array}$ & $\begin{array}{c}441 \\
302 \\
140 \\
97 \\
205 \\
22564\end{array}$ & $\begin{array}{l}(403) \\
(352) \\
(178) \\
(114) \\
(289) \\
(21530)\end{array}$ \\
\hline \multicolumn{7}{|l|}{ Crime Rates: } \\
\hline $\begin{array}{l}\mathrm{SC} / \mathrm{ST} \text { total crime rate } \\
\mathrm{SC} / \mathrm{ST} \text { IPC crime rate } \\
\mathrm{SC} / \mathrm{ST} \text { SLL crime rate } \\
\mathrm{SC} / \mathrm{ST} \text { body crime rate } \\
\mathrm{SC} / \mathrm{ST} \text { non-body crime rate } \\
\text { General crime rate }\end{array}$ & $\begin{array}{c}99.8 \\
66.5 \\
33.3 \\
23.1 \\
43.5 \\
1544.3\end{array}$ & $\begin{array}{c}(135.1) \\
(107.1) \\
(52.7) \\
(42.1) \\
(75.4) \\
(1492.7)\end{array}$ & $\begin{array}{c}104.4 \\
68.9 \\
35.5 \\
24 \\
44.9 \\
1552.9\end{array}$ & $\begin{array}{c}(164.3) \\
(125.6) \\
(58.6) \\
(44.3) \\
(89.6) \\
(1884.3)\end{array}$ & $\begin{array}{c}95.3 \\
64.2 \\
31.2 \\
22.2 \\
42 \\
1535.7\end{array}$ & $\begin{array}{l}(97.7) \\
(84.6) \\
(46) \\
(39.7) \\
(57.9) \\
(954.5)\end{array}$ \\
\hline \multicolumn{7}{|l|}{ Explanatory Variables: } \\
\hline $\begin{array}{l}\text { SCST MPCE/Upper Caste MPCE } \\
\text { MPCE } \\
\text { SCST MPCE } \\
\text { Upper Caste MPCE } \\
\text { Other Backward Classes MPCE } \\
\text { \% SC/ST Population } \\
\text { \% Rural Population } \\
\text { \% Underemployed } \\
\text { \% Young males } \\
\text { Gini (based on MPCE) } \\
\text { Effective number of political parties } \\
\text { \% Illiterate } \\
\text { \% Primary Education } \\
\text { \% Secondary Education } \\
\text { \% Higher secondary and above education }\end{array}$ & $\begin{array}{c}0.68 \\
535.1 \\
433.17 \\
679.07 \\
523.11 \\
29.8 \\
79.39 \\
16.02 \\
9.41 \\
0.25 \\
4.6 \\
45.87 \\
19.92 \\
24.06 \\
10.15\end{array}$ & $\begin{array}{l}(0.16) \\
(186.3) \\
(128.2) \\
(274.2) \\
(179.1) \\
(15.2) \\
(17.3) \\
(7.6) \\
(1.9) \\
(0.05) \\
(1.3) \\
(15.4) \\
(6.4) \\
(9.1) \\
(5.7)\end{array}$ & $\begin{array}{c}0.71 \\
471.3 \\
394.53 \\
574.53 \\
459.39 \\
29.9 \\
79.31 \\
15.33 \\
9.31 \\
0.24 \\
4.4 \\
47.9 \\
19.56 \\
23.34 \\
9.06\end{array}$ & $\begin{array}{c}(0.16) \\
(132.2) \\
(100.6) \\
(172.2) \\
(126.3) \\
(15.5) \\
(18.1) \\
(7.5) \\
(1.7) \\
(0.04) \\
(1.3) \\
(15.6) \\
(6.6) \\
(9.4) \\
(5.2)\end{array}$ & $\begin{array}{c}0.64 \\
598.9 \\
471.72 \\
783.85 \\
585.9 \\
29.6 \\
79.48 \\
16.7 \\
9.52 \\
0.27 \\
4.7 \\
43.8 \\
20.18 \\
24.78 \\
11.24\end{array}$ & $\begin{array}{c}(0.17) \\
(209.5) \\
(140.8) \\
(314.7) \\
(200.2) \\
(15) \\
(16.5) \\
(7.5) \\
(2) \\
(0.06) \\
(1.4) \\
(14.9) \\
(6.1) \\
(8.7) \\
(6.1)\end{array}$ \\
\hline
\end{tabular}

Note: 'Total crimes against SC/ST' is the sum of IPC and SLL crimes against them. IPC crimes are the sum of murder, rape, kidnap, hurt, dacoity, robbery, arson and other IPC crimes. SLL crimes are the sum of crimes registered under the Prevention of Atrocities Act and the Protection of Civil Rights Act. IPC body Crimes are the sum of murder, rape, kidnapping and physical assault. IPC non-body crimes are the sum of dacoity, robbery, arson and other IPC crimes. Mean and standard deviation for numbers of crimes have been rounded off to whole numbers. Crime rate against SCs/STs computed per $100000 \mathrm{SC} / \mathrm{ST}$ population. General crime is total IPC crimes less IPC crimes against SC/ST (proxy for crimes against non-SCSTs). General crime rate is calculated per 100000 non-SC/ST population. Young males refer to males in the 15-24 age groups. MPCE refers to real monthly per capita expenditure. The formula for effective number of parties is $n=1 / \Sigma p_{i}^{2}$ where $p_{i}$ is the proportion of votes received by party $i$ in the state elections. Instead of using the total number of parties, this measure places greater weight on parties that have a higher share of votes as compared to those with a low vote share. 
Table 2: Effect of Relative Economic Status on Crimes against SCs/STs

\begin{tabular}{|c|c|c|c|}
\hline & Total Crime Rate & IPC Crime Rate & SLL Crime Rate \\
\hline Ln (SCST exp/UC exp) & $\begin{array}{l}0.304^{* *} \\
(0.118)\end{array}$ & $\begin{array}{l}0.355^{* *} \\
(0.149)\end{array}$ & $\begin{array}{c}0.298 \\
(0.294)\end{array}$ \\
\hline Ln (Expenditure) & $\begin{array}{c}-0.008 \\
(0.283)\end{array}$ & $\begin{array}{l}-0.378 \\
(0.389)\end{array}$ & $\begin{array}{c}0.413 \\
(0.591)\end{array}$ \\
\hline \% SCST Population & $\begin{array}{c}-0.087^{* * *} \\
(0.0096)\end{array}$ & $\begin{array}{l}-0.1^{* * *} \\
(0.011)\end{array}$ & $\begin{array}{c}-0.08^{* * *} \\
(0.022)\end{array}$ \\
\hline \% SCST Population squared & $\begin{array}{c}0.0007^{* * *} \\
(0.0001)\end{array}$ & $\begin{array}{c}0.0009^{* * *} \\
(0.0001)\end{array}$ & $\begin{array}{l}0.0006^{* *} \\
(0.0003)\end{array}$ \\
\hline$\%$ Rural Population & $\begin{array}{c}0.005 \\
(0.0041)\end{array}$ & $\begin{array}{c}0.0004 \\
(0.0053)\end{array}$ & $\begin{array}{c}0.005 \\
(0.0098)\end{array}$ \\
\hline Gini & $\begin{array}{l}1.050 \\
(1.009)\end{array}$ & $\begin{array}{l}2.656^{* *} \\
(1.239)\end{array}$ & $\begin{array}{c}-0.378 \\
(1.942)\end{array}$ \\
\hline Underemployment Rate & $\begin{array}{c}0.003 \\
(0.0043)\end{array}$ & $\begin{array}{c}0.003 \\
(0.0058)\end{array}$ & $\begin{array}{c}0.011 \\
(0.0089)\end{array}$ \\
\hline$\%$ Young Males & $\begin{array}{c}-0.014 \\
(0.0163)\end{array}$ & $\begin{array}{c}0.022 \\
(0.0241)\end{array}$ & $\begin{array}{c}-0.031 \\
(0.0343)\end{array}$ \\
\hline$\%$ Illiterate & $\begin{array}{c}-0.01 \\
(0.0096)\end{array}$ & $\begin{array}{c}-0.001 \\
(0.0131)\end{array}$ & $\begin{array}{c}-0.019 \\
(0.0217)\end{array}$ \\
\hline$\%$ Primary Education & $\begin{array}{c}0.008 \\
(0.0129)\end{array}$ & $\begin{array}{c}0.007 \\
(0.0165)\end{array}$ & $\begin{array}{c}0.005 \\
(0.024)\end{array}$ \\
\hline$\%$ Secondary Education & $\begin{array}{c}-0.0021 \\
(0.0132)\end{array}$ & $\begin{array}{c}-0.0083 \\
(0.0177)\end{array}$ & $\begin{array}{c}0.001 \\
(0.0272)\end{array}$ \\
\hline Effective Number of Parties & $\begin{array}{c}0.0344 \\
(0.0716)\end{array}$ & $\begin{array}{c}0.134 \\
(0.0977)\end{array}$ & $\begin{array}{c}-0.386^{* *} \\
(0.162)\end{array}$ \\
\hline $\begin{array}{l}\text { Number of districts } \\
\mathrm{F} \\
R^{2}\end{array}$ & $\begin{array}{c}828 \\
16.45 \\
0.342\end{array}$ & $\begin{array}{c}828 \\
9.96 \\
0.221\end{array}$ & $\begin{array}{c}828 \\
4.53 \\
0.126\end{array}$ \\
\hline
\end{tabular}

Note: Standard errors clustered at the district level are reported in parentheses. *** significant at $1 \%,{ }^{* *}$ significant at $5 \%,{ }^{*}$ significant at $10 \%$. All regressions include district fixed effects, time dummy and a constant term. All dependent variables are in logarithm terms. Crime rate is number of crimes per $100000 \mathrm{SC} / \mathrm{ST}$ population. IPC crimes are the sum of murder, rape, kidnap, hurt, dacoity, robbery, arson and other IPC crimes. SLL crimes are the sum of crimes registered under the Prevention of Atrocities Act and the Protection of Civil Rights Act. For education dummy variables, 'higher secondary and above' is the omitted category. 
Table 3: Effect of Group-wise Expenditures on Total, IPC and SLL Crime Rates

\begin{tabular}{|c|c|c|c|}
\hline & Total Crime Rate & IPC Crime Rate & SLL Crime Rate \\
\hline Ln (SCST Expenditure) & $\begin{array}{c}0.138 \\
(0.191)\end{array}$ & $\begin{array}{l}-0.134 \\
(0.309)\end{array}$ & $\begin{array}{c}0.496 \\
(0.474)\end{array}$ \\
\hline Ln (UC Expenditure) & $\begin{array}{c}-0.341^{* *} \\
(0.143)\end{array}$ & $\begin{array}{c}-0.563^{* * *} \\
(0.185)\end{array}$ & $\begin{array}{l}-0.158 \\
(0.341)\end{array}$ \\
\hline Ln (OBC Expenditure) & $\begin{array}{l}-0.0393 \\
(0.196)\end{array}$ & $\begin{array}{c}0.112 \\
(0.319)\end{array}$ & $\begin{array}{l}-0.107 \\
(0.454)\end{array}$ \\
\hline \% SCST Population & $\begin{array}{c}-0.091^{* * *} \\
(0.009)\end{array}$ & $\begin{array}{c}-0.097^{* * *} \\
(0.0109)\end{array}$ & $\begin{array}{c}-0.091^{* * *} \\
(0.0251)\end{array}$ \\
\hline$\%$ SCST Population squared & $\begin{array}{c}0.0008^{* * *} \\
(0.0001)\end{array}$ & $\begin{array}{c}0.0009^{* * *} \\
(0.0001)\end{array}$ & $\begin{array}{l}0.0008^{* *} \\
(0.0003)\end{array}$ \\
\hline$\%$ Rural Population & $\begin{array}{c}0.0052 \\
(0.0041)\end{array}$ & $\begin{array}{l}-0.0004 \\
(0.0053)\end{array}$ & $\begin{array}{c}0.006 \\
(0.0102)\end{array}$ \\
\hline Gini & $\begin{array}{c}0.978 \\
(0.936)\end{array}$ & $\begin{array}{l}2.652^{* *} \\
(1.142)\end{array}$ & $\begin{array}{c}-0.393 \\
(1.898)\end{array}$ \\
\hline Underemployment Rate & $\begin{array}{c}0.0009 \\
(0.0043)\end{array}$ & $\begin{array}{c}0.002 \\
(0.0057)\end{array}$ & $\begin{array}{c}0.0109 \\
(0.0095)\end{array}$ \\
\hline$\%$ Young Males & $\begin{array}{l}-0.0163 \\
(0.0158)\end{array}$ & $\begin{array}{c}0.0269 \\
(0.0253)\end{array}$ & $\begin{array}{l}-0.0448 \\
(0.0349)\end{array}$ \\
\hline$\%$ Illiterate & $\begin{array}{l}-0.0077 \\
(0.0098)\end{array}$ & $\begin{array}{c}0.0031 \\
(0.0131)\end{array}$ & $\begin{array}{l}-0.0195 \\
(0.0211)\end{array}$ \\
\hline \% Primary Education & $\begin{array}{c}0.0092 \\
(0.0133)\end{array}$ & $\begin{array}{c}0.0093 \\
(0.0164)\end{array}$ & $\begin{array}{c}0.0045 \\
(0.0239)\end{array}$ \\
\hline$\%$ Secondary Education & $\begin{array}{c}0.0045 \\
(0.0128)\end{array}$ & $\begin{array}{c}0.0028 \\
(0.0166)\end{array}$ & $\begin{array}{c}0.0043 \\
(0.0276)\end{array}$ \\
\hline Effective Number of Parties & $\begin{array}{c}0.0428 \\
(0.0707) \\
\end{array}$ & $\begin{array}{c}0.151 \\
(0.0975) \\
\end{array}$ & $\begin{array}{c}-0.396^{* *} \\
(0.164) \\
\end{array}$ \\
\hline Number of districts & 818 & 818 & 818 \\
\hline $\mathrm{F}$ & 15.81 & 9.54 & 4.25 \\
\hline$R^{2}$ & 0.345 & 0.218 & 0.127 \\
\hline
\end{tabular}

Note: Standard errors clustered at the district level are reported in parentheses. ${ }^{* * *}$ significant at $1 \%,{ }^{* *}$ significant at $5 \%,{ }^{*}$ significant at $10 \%$. All regressions include district fixed effects, time dummy and a constant term. All dependent variables are in logarithm terms. Crime rate is number of crimes per $100000 \mathrm{SC} / \mathrm{ST}$ population. IPC crimes are the sum of murder, rape, kidnap, hurt, dacoity, robbery, arson and other IPC crimes. SLL crimes are the sum of crimes registered under the Prevention of Atrocities Act and the Protection of Civil Rights Act. For education dummy variables, 'higher secondary and above' is the omitted category. 


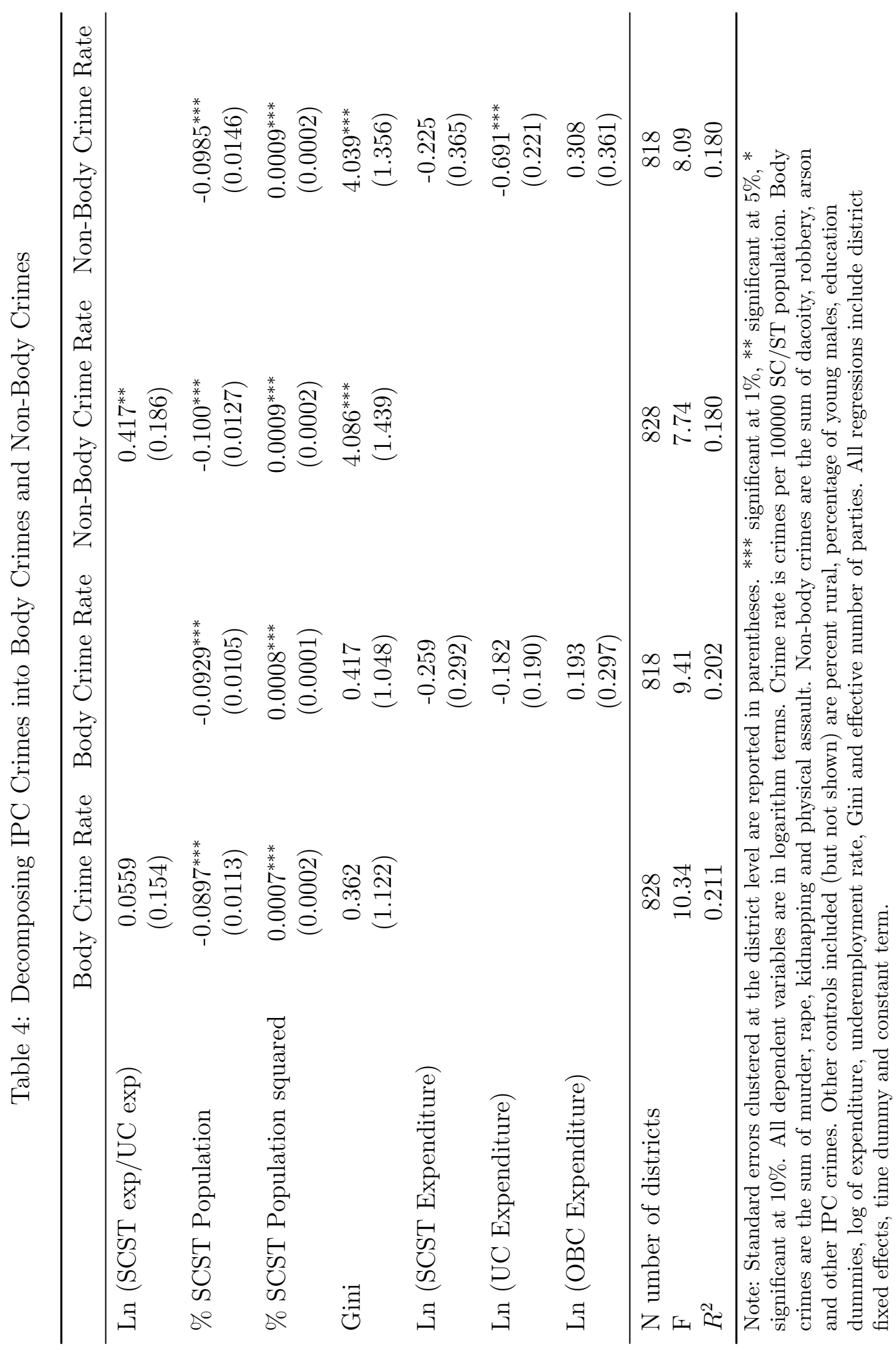




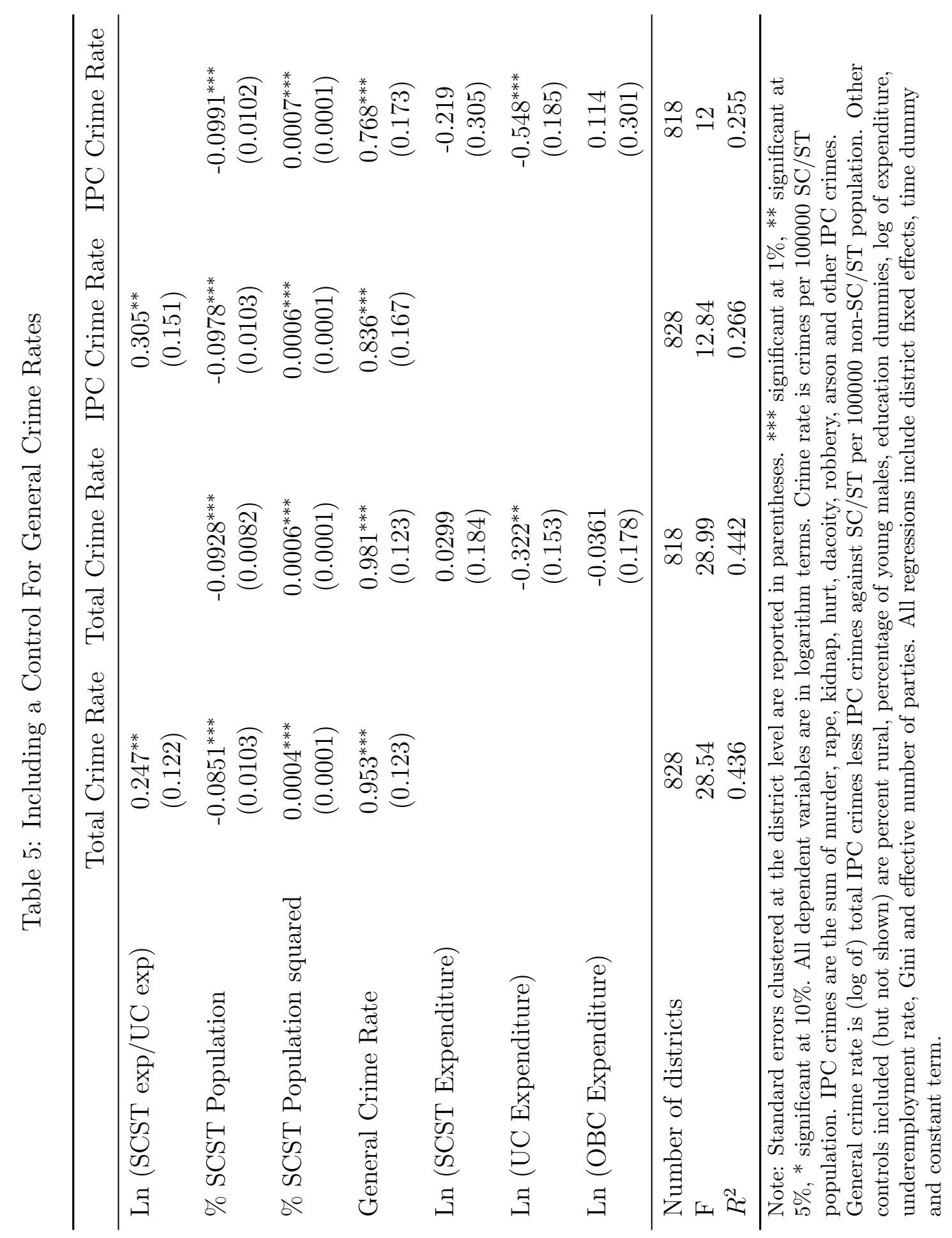


Table 6: Negative Binomial Regressions

Table 6.A Negative Binomial Regressions using total crimes against SC/ST

\begin{tabular}{lcccc}
\hline & Total Crimes & Total Crimes & Total Crimes & Total Crimes \\
\hline Ln (SCST exp/UC exp) & $0.263^{* *}$ & $0.248^{* *}$ & & \\
& $(0.104)$ & $(0.102)$ & & \\
General Crime Rate & & $0.427^{* * *}$ & & $0.421^{* * *}$ \\
& $(0.0904)$ & & $(0.0997)$ \\
Ln (SCST Expenditure) & & 0.212 & 0.198 \\
& & $(0.164)$ & $(0.161)$ \\
Ln (UC Expenditure) & & $-0.265^{* *}$ & $-0.263^{* *}$ \\
& & & $(0.122)$ & $(0.121)$ \\
Ln (OBC Expenditure) & & & 0.179 & 0.140 \\
& & & $(0.159)$ & $(0.159)$ \\
\hline Number of districts & 824 & 824 & 806 & 806 \\
\hline
\end{tabular}

Note: Standard errors are reported in parentheses. ${ }^{* * *}$ significant at $1 \%,{ }^{* *}$ significant at $5 \%,{ }^{*}$ significant at 10\%. Other variables included (but not shown) are SCST\%, SCST\% squared, percent rural, percentage of young males, education dummies, log of expenditure, underemployment rate, Gini and effective number of parties. SC/ST population is used as scaling variable on right hand side. General crime rate is (log of) total IPC crimes less IPC crimes against SC/ST per 100000 non-SC/ST population.

Table 6.B Negative Binomial Regressions using IPC crimes against SC/ST

\begin{tabular}{lcccc}
\hline & IPC Crimes & IPC Crimes & IPC Crimes & IPC Crimes \\
\hline Ln (SCST exp/UC exp) & $0.286^{* *}$ & $0.289^{* *}$ & & \\
& $(0.137)$ & $(0.136)$ & & \\
General Crime Rate & & $0.258^{* *}$ & & $0.214^{*}$ \\
& $(0.106)$ & & $(0.113)$ \\
Ln (SCST Expenditure) & & -0.0492 & -0.0735 \\
& & $(0.214)$ & $(0.213)$ \\
Ln (UC Expenditure) & & $-0.441^{* * *}$ & $-0.457^{* * *}$ \\
& & & $(0.159)$ & $(0.159)$ \\
Ln (OBC Expenditure) & & 0.290 & 0.291 \\
& & & $(0.195)$ & $(0.196)$ \\
\hline
\end{tabular}

\begin{tabular}{|c|c|c|c|c|}
\hline Number of districts & 820 & 820 & 802 & 802 \\
\hline
\end{tabular}
significant at 10\%. Other variables included (but not shown) are SCST\%, SCST\% squared, percent rural, percentage of young males, education dummies, log of expenditure, underemployment rate, Gini and effective number of parties. SC/ST population is used as scaling variable on right hand side. GGeneral crime rate is (log of) total IPC crimes less IPC crimes against SC/ST per 100000 non-SC/ST population. 
Table 7: Regressions using General Crimes as Dependent Variable

Table 7.A Linear Fixed Effects Regressions using General Crime Rate as Dependent Variable

\begin{tabular}{lcc}
\hline & General Crime Rate & General Crime Rate \\
\hline Ln (SCST exp/UC exp) & 0.06 & \\
& $(0.0526)$ & 0.11 \\
Ln (SCST Expenditure) & & $(0.0926)$ \\
& & -0.0191 \\
Ln (UC Expenditure) & & $(0.0595)$ \\
& 828 & -0.00324 \\
Ln (OBC Expenditure) & 14.07 & $(0.0991)$ \\
& 0.394 & 818 \\
Number of districts & & 13.99 \\
F & & 0.373 \\
\hline$R^{2}$ & & \\
\hline
\end{tabular}

Note: Standard errors clustered at the district level are reported in parentheses. ${ }^{* * *}$ significant at $1 \%, * *$ significant at $5 \%, *$ significant at $10 \%$. All dependent variables are in logarithm terms. All regressions include district fixed effects, time dummy and constant term. Other controls used but not shown include SCST\%, SCST\% squared, percent rural, percentage of young males, education dummies, log of expenditure, underemployment rate, Gini and effective number of parties. General crime rate is (log of) total IPC crimes less IPC crimes against SC/ST per 100000 non-SC/ST population.

Table 7.B Negative Binomial Regressions using General Crimes as Dependent Variable

\begin{tabular}{lcc}
\hline & General Crimes & General Crimes \\
\hline Ln (SCST exp/UC exp) & 0.0452 & \\
& $(0.0372)$ & 0.0749 \\
Ln (SCST Expenditure) & $(0.0577)$ \\
& & -0.0247 \\
Ln (UC Expenditure) & $(0.0421)$ \\
Ln (OBC Expenditure) & -0.0113 \\
\end{tabular}

\begin{tabular}{l} 
Number of districts $826 \quad 808$ \\
\hline Note: Standard errors are reported in parentheses. ${ }^{* *}$ significant at $1 \%,{ }^{* *}$ significant at $5 \%,{ }^{*}$ \\
significant at $10 \%$. Other variables included (but not shown) are SCST\%, SCST\% squared, percent \\
rural, percentage of young males, education dummies, log of expenditure, underemployment rate, Gini \\
and effective number of parties. Non-SC/ST population is used as scaling variable on right hand side. \\
General crimes are total IPC crimes less IPC crimes against SC/ST.
\end{tabular}




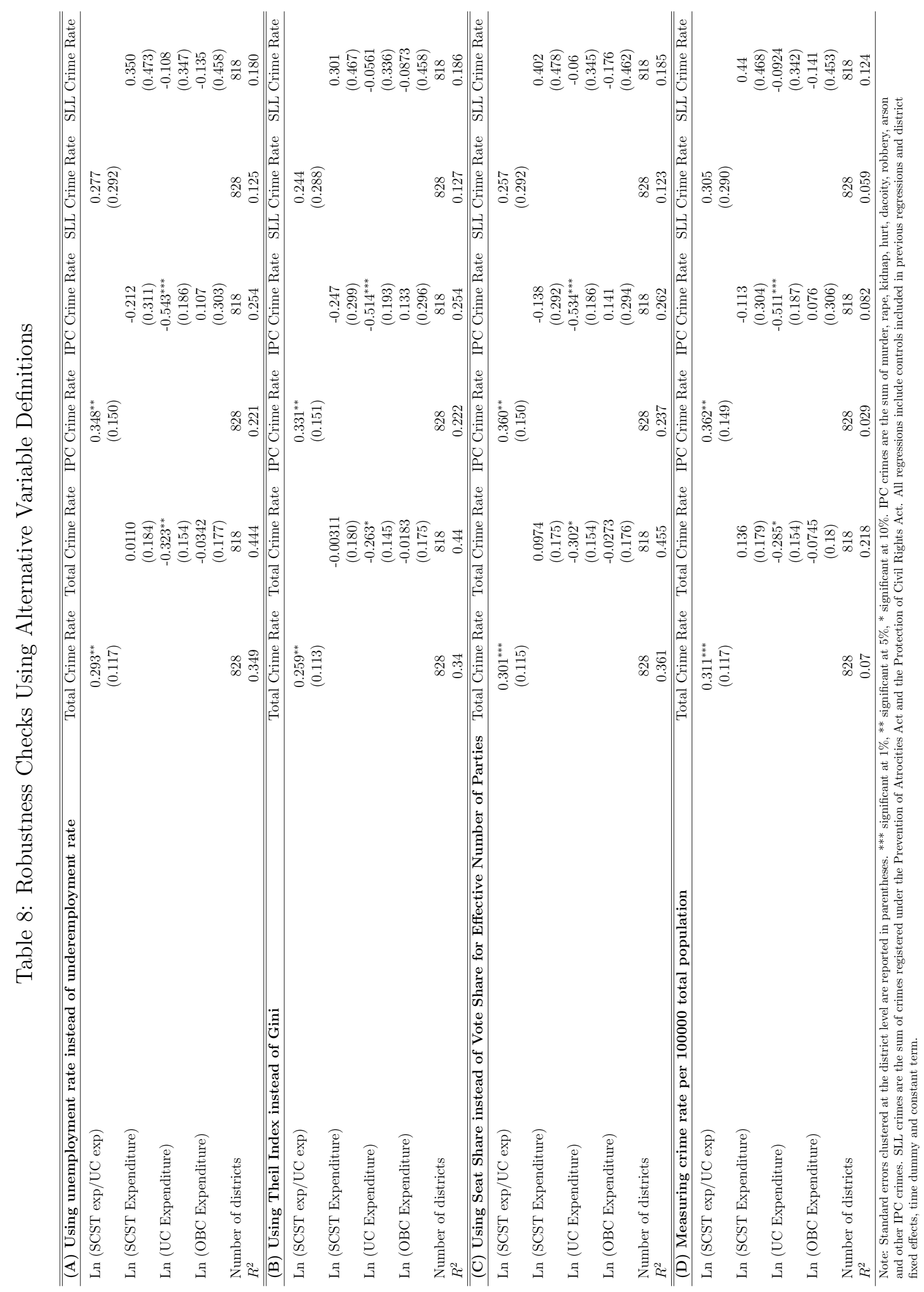


Table 9: Excluding States One At a Time: Relative Expenditure Specification

\begin{tabular}{|c|c|c|c|}
\hline & Excl. Andhra Pr. & Excl.Bihar & Excl.Chhattisgarh \\
\hline \multirow[t]{2}{*}{ Ln (SCST exp/UC exp) } & $0.250^{* *}$ & $0.237^{* *}$ & $0.269^{* *}$ \\
\hline & $(0.124)$ & $(0.117)$ & $(0.122)$ \\
\hline Number of districts & 782 & 760 & 814 \\
\hline \multirow[t]{2}{*}{$R^{2}$} & 0.432 & 0.453 & 0.443 \\
\hline & Excl. Gujarat & Excl. Haryana & Excl. Himachal Pr. \\
\hline \multirow[t]{2}{*}{ Ln (SCST exp/UC exp) } & $0.264^{* *}$ & $0.253^{* *}$ & $0.243^{* *}$ \\
\hline & $(0.125)$ & $(0.123)$ & $(0.123)$ \\
\hline Number of districts & 793 & 796 & 806 \\
\hline \multirow[t]{2}{*}{$R^{2}$} & 0.448 & 0.421 & 0.447 \\
\hline & Excl. Jharkhand & Excl. Karnataka & Excl. Kerala \\
\hline \multirow[t]{2}{*}{ Ln (SCST exp/UC exp) } & $0.207^{*}$ & $0.234^{*}$ & $0.253^{* *}$ \\
\hline & $(0.110)$ & $(0.125)$ & $(0.124)$ \\
\hline Number of districts & 792 & 788 & 800 \\
\hline \multirow[t]{2}{*}{$R^{2}$} & 0.440 & 0.436 & 0.435 \\
\hline & Excl. Madhya Pr. & Excl. Maharashtra & Excl. Orissa \\
\hline \multirow[t]{2}{*}{ Ln (SCST exp/UC exp) } & $0.241^{*}$ & $0.255^{*}$ & $0.235^{*}$ \\
\hline & $(0.134)$ & $(0.134)$ & $(0.121)$ \\
\hline Number of districts & 752 & 768 & 768 \\
\hline \multirow[t]{2}{*}{$R^{2}$} & 0.432 & 0.428 & 0.484 \\
\hline & Excl. Punjab & Excl. Rajasthan & Excl. Tamil Nadu \\
\hline \multirow[t]{2}{*}{ Ln (SCST exp/UC exp) } & $0.245^{* *}$ & $0.258^{* *}$ & $0.305^{* *}$ \\
\hline & $(0.122)$ & $(0.128)$ & $(0.143)$ \\
\hline Number of districts & 800 & 768 & 783 \\
\hline \multirow[t]{2}{*}{$R^{2}$} & 0.439 & 0.426 & 0.441 \\
\hline & Excl. Uttar Pr. & Excl. Uttarkhand & Excl. West Bengal \\
\hline \multirow[t]{2}{*}{ Ln (SCST exp/UC exp) } & $0.271^{*}$ & $0.210^{*}$ & $0.230^{*}$ \\
\hline & $(0.138)$ & $(0.123)$ & $(0.118)$ \\
\hline Number of districts & 704 & 808 & 794 \\
\hline$R^{2}$ & 0.390 & 0.441 & 0.446 \\
\hline
\end{tabular}

\begin{tabular}{lc}
\hline & Excl. UP, MP and Rajasthan \\
\hline Ln (SCST exp/UC exp) & $0.326^{* *}$ \\
& $(0.162)$ \\
Number of districts & 568 \\
$R^{2}$ & 0.32 \\
\hline
\end{tabular}

Note: Note: Standard errors clustered at the district level are reported in parentheses. ${ }^{* * *}$ significant at $1 \%, * *$ significant at $5 \%, *$ significant at $10 \%$. Crime rate is crimes per $100000 \mathrm{SC} / \mathrm{ST}$ population. Other controls included (but not shown) are percent rural, percentage of young males, education dummies, log of expenditure, underemployment rate, Gini, effective number of parties and log of general crime rate. All regressions include district fixed effects, time dummy and constant term. 
Table 10: Excluding States One At a Time: Group-wise Expenditure Specification

\begin{tabular}{|c|c|c|c|}
\hline & Excl. Andhra Pr. & Excl.Bihar & Excl.Chhattisgarh \\
\hline Ln (SCST Expenditure) & $\begin{array}{l}-0.005 \\
(0.190)\end{array}$ & $\begin{array}{l}-0.024 \\
(0.176)\end{array}$ & $\begin{array}{c}0.059 \\
(0.185)\end{array}$ \\
\hline Ln (UC Expenditure) & $\begin{array}{c}-0.338^{* *} \\
(0.154)\end{array}$ & $\begin{array}{c}-0.330^{* *} \\
(0.148)\end{array}$ & $\begin{array}{c}-0.343^{* *} \\
(0.153)\end{array}$ \\
\hline Ln (OBC Expenditure) & $\begin{array}{l}-0.004 \\
(0.183)\end{array}$ & $\begin{array}{c}-0.014 \\
(0.174)\end{array}$ & $\begin{array}{c}-0.069 \\
(0.178)\end{array}$ \\
\hline $\begin{array}{l}\text { Number of districts } \\
R^{2}\end{array}$ & $\begin{array}{c}772 \\
0.438\end{array}$ & $\begin{array}{c}750 \\
0.456\end{array}$ & $\begin{array}{c}804 \\
0.448\end{array}$ \\
\hline & Excl. Gujarat & Excl. Haryana & Excl. Himachal Pr. \\
\hline Ln (SCST Expenditure) & $\begin{array}{c}0.080 \\
(0.188)\end{array}$ & $\begin{array}{c}0.020 \\
(0.188)\end{array}$ & $\begin{array}{c}0.021 \\
(0.192)\end{array}$ \\
\hline Ln (UC Expenditure) & $\begin{array}{l}-0.322^{* *} \\
(0.158)\end{array}$ & $\begin{array}{l}-0.329^{* *} \\
(0.154)\end{array}$ & $\begin{array}{r}-0.326^{* *} \\
(0.152)\end{array}$ \\
\hline Ln (OBC Expenditure) & $\begin{array}{c}-0.075 \\
(0.182)\end{array}$ & $\begin{array}{c}0.009 \\
(0.182)\end{array}$ & $\begin{array}{c}-0.025 \\
(0.202)\end{array}$ \\
\hline $\begin{array}{l}\text { Number of districts } \\
R^{2}\end{array}$ & $\begin{array}{c}783 \\
0.453\end{array}$ & $\begin{array}{c}786 \\
0.427\end{array}$ & $\begin{array}{c}800 \\
0.440\end{array}$ \\
\hline & Excl. Jharkhand & Excl. Karnataka & Excl. Kerala \\
\hline Ln (SCST Expenditure) & $\begin{array}{c}0.020 \\
(0.185)\end{array}$ & $\begin{array}{c}0.077 \\
(0.188)\end{array}$ & $\begin{array}{c}0.044 \\
(0.189)\end{array}$ \\
\hline Ln (UC Expenditure) & $\begin{array}{c}-0.258^{*} \\
(0.135)\end{array}$ & $\begin{array}{c}-0.281^{*} \\
(0.156)\end{array}$ & $\begin{array}{c}-0.320^{* *} \\
(0.156)\end{array}$ \\
\hline Ln (OBC Expenditure) & $\begin{array}{l}-0.032 \\
(0.173)\end{array}$ & $\begin{array}{l}-0.018 \\
(0.185)\end{array}$ & $\begin{array}{c}-0.044 \\
(0.181)\end{array}$ \\
\hline $\begin{array}{l}\text { Number of districts } \\
R^{2}\end{array}$ & $\begin{array}{c}782 \\
0.450\end{array}$ & $\begin{array}{c}778 \\
0.440\end{array}$ & $\begin{array}{c}790 \\
0.441\end{array}$ \\
\hline & Excl. Madhya Pr. & Excl. Maharashtra & Excl. Orissa \\
\hline Ln (SCST Expenditure) & $\begin{array}{l}-0.019 \\
(0.192)\end{array}$ & $\begin{array}{c}0.010 \\
(0.198)\end{array}$ & $\begin{array}{c}0.087 \\
(0.185)\end{array}$ \\
\hline Ln (UC Expenditure) & $\begin{array}{l}-0.310^{*} \\
(0.166)\end{array}$ & $\begin{array}{l}-0.327^{*} \\
(0.171)\end{array}$ & $\begin{array}{l}-0.297^{*} \\
(0.158)\end{array}$ \\
\hline Ln (OBC Expenditure) & $\begin{array}{l}-0.086 \\
(0.184)\end{array}$ & $\begin{array}{l}-0.055 \\
(0.182)\end{array}$ & $\begin{array}{c}-0.078 \\
(0.186)\end{array}$ \\
\hline $\begin{array}{l}\text { Number of districts } \\
R^{2}\end{array}$ & $\begin{array}{l}742 \\
0.441\end{array}$ & $\begin{array}{c}758 \\
0.434\end{array}$ & $\begin{array}{c}758 \\
0.495\end{array}$ \\
\hline & Excl. Punjab & Excl. Rajasthan & Excl. Tamil Nadu \\
\hline Ln (SCST Expenditure) & $\begin{array}{c}-0.003 \\
(0.186)\end{array}$ & $\begin{array}{c}0.013 \\
(0.195)\end{array}$ & $\begin{array}{c}0.087 \\
(0.190)\end{array}$ \\
\hline Ln (UC Expenditure) & $\begin{array}{c}-0.330^{* *} \\
(0.152)\end{array}$ & $\begin{array}{c}-0.350^{* *} \\
(0.161)\end{array}$ & $\begin{array}{c}-0.395^{* *} \\
(0.183)\end{array}$ \\
\hline Ln (OBC Expenditure) & $\begin{array}{l}-0.019 \\
(0.187)\end{array}$ & $\begin{array}{c}-0.039 \\
(0.190)\end{array}$ & $\begin{array}{c}-0.002 \\
(0.181)\end{array}$ \\
\hline $\begin{array}{l}\text { Number of districts } \\
R^{2}\end{array}$ & $\begin{array}{c}790 \\
0.445\end{array}$ & $\begin{array}{c}758 \\
0.432\end{array}$ & $\begin{array}{c}773 \\
0.447\end{array}$ \\
\hline & Excl. Uttar Pr. & Excl. Uttarkhand & Excl. West Bengal \\
\hline Ln (SCST Expenditure) & $\begin{array}{c}0.042 \\
(0.218)\end{array}$ & $\begin{array}{c}0.042 \\
(0.185)\end{array}$ & $\begin{array}{l}-0.048 \\
(0.176)\end{array}$ \\
\hline Ln (UC Expenditure) & $\begin{array}{c}-0.343^{* *} \\
(0.170)\end{array}$ & $\begin{array}{l}-0.295^{*} \\
(0.150)\end{array}$ & $\begin{array}{c}-0.320^{* *} \\
(0.152)\end{array}$ \\
\hline Ln (OBC Expenditure) & $\begin{array}{c}-0.029 \\
(0.190)\end{array}$ & $\begin{array}{c}-0.035 \\
(0.178)\end{array}$ & $\begin{array}{c}-0.032 \\
(0.178)\end{array}$ \\
\hline $\begin{array}{l}\text { Number of districts } \\
R^{2}\end{array}$ & $\begin{array}{c}694 \\
0.393\end{array}$ & $\begin{array}{c}804 \\
0.453\end{array}$ & $\begin{array}{l}784 \\
0.454\end{array}$ \\
\hline \multicolumn{4}{|c|}{ 1. UP, MP and Rajasthan } \\
\hline Ln (SCST exp) & $\begin{array}{l}-0.016 \\
(0.253)\end{array}$ & & \\
\hline Ln (UC exp) & $\begin{array}{l}-0.358^{*} \\
(0.188)\end{array}$ & & \\
\hline Ln (OBC exp) & $\begin{array}{l}-0.176 \\
(0.234)\end{array}$ & & \\
\hline $\begin{array}{l}\text { Number of districts } \\
R^{2}\end{array}$ & $\begin{array}{c}558 \\
0.343\end{array}$ & & \\
\hline
\end{tabular}




\section{A Crimes against Scheduled Castes and Tribes in- cluded under the Special and Local Laws (SLL) category}

1) The Protection of Civil Rights Act, 1955

Sections 3 - 7A of the Act define the following as offences if committed on the ground of "untouchability":

1. Prevention from entering public worship places, using sacred water resources.

2. Denial of access to any shop, public restaurant, hotel, public entertainment, cremation ground etc.

3. Refusal of admission to any hospital, dispensary, educational institutions etc.

4. Refusal to sell goods and render services.

5. Molestation, causing injury, insult etc.

6. Compelling a person on the ground of untouchability to do any scavenging or sweeping or to remove any carcass etc.

(2) The Scheduled Castes and Scheduled Tribes (Prevention of Atrocities) Act, 1989

Whoever, not being a member of a Scheduled Caste or a Scheduled Tribe:

1. Forces a member of a Scheduled Caste or a Scheduled Tribe to drink or eat any inedible or obnoxious substance;

2. Acts with intent to cause injury, insult or annoyance to any member of a Scheduled Caste or a Scheduled Tribe by dumping excreta, waste matter, carcasses or any other obnoxious substance in his premises or neighbourhood;

3. Forcibly removes clothes from the person of a member of a Scheduled Caste or a Scheduled Tribe or parades him naked or with painted face or body or commits any similar act which is derogatory to human dignity;

4. Wrongfully occupies or cultivates any land owned by, or allotted to, or notified by any competent authority to be allotted to, a member of a Scheduled Caste or a Scheduled Tribe or gets the land allotted to him transferred; 
5. Wrongfully dispossesses a member of a Scheduled Caste or a Scheduled Tribe from his land or premises or interferes with the enjoyment of his rights over any land, premises or water;

6. Compels or entices a member of a Scheduled Caste or a Scheduled Tribe to do 'begar' or other similar forms of forced or bonded labour other than any compulsory service for public purposes imposed by Government;

7. Forces or intimidates a member of a Scheduled Caste or a Scheduled Tribe not to vote or vote for a particular candidate or to vote in a manner other than that provided by law;

8. Institutes false, malicious or vexatious suit or criminal or other proceedings against a member of a Scheduled Caste or a Scheduled Tribe;

9. Gives any false or frivolous information to any public servant and thereby causes such public servant to use his lawful power to the injury or annoyance of a member of a Scheduled Caste or a Scheduled Tribe;

10. Intentionally insults or intimidates with intent to humiliate a member of a Scheduled Caste or a Scheduled Tribe;

11. Assaults or uses force to any woman belonging to a Scheduled Caste or a Scheduled Tribe with intent to dishonour or outrage her modesty;

12. Being in a position to dominate the will of a woman belonging to a Scheduled Caste or a Scheduled Tribe and uses that position to exploit her sexually to which she would not have otherwise agreed;

13. Corrupts or fouls the water of any spring, reservoir, or any other source ordinarily used by members of the Scheduled Caste or the Scheduled Tribe so as to render it less fit for the purpose for which it is ordinarily used;

14. Denies a member of a Scheduled Caste or a Scheduled Tribe any customary rite of passage to a place of public resort or obstructs such members so as to prevent him for using or having access to a place of public resort to which other members of public or any section thereof have a right to use or access to;

15. Forces or causes a member of a Scheduled Caste or a Scheduled Tribe to leave his house, village, or any other place of residence. 


\section{B Real Monthly Per Capita Expenditure Calcula- tion}

This section discusses the calculation of monthly per capita expenditure using NSS consumer expenditure surveys of 1999-2000 and 2004-05.

Reference period: This is the period of time to which the information collected relates. It may vary from item to item. Mixed Reference Period (MRP) refers to 365-day recall for low-frequency items and 30-day recall for everything else. Uniform Reference Period refers to 30-day recall for all items (high and low frequency)

NSS 61st Consumer Expenditure Survey (2004-05): The reference periods used in the 61st round for different groups of consumption items are given below:

1. 'Last 30 days': all food; pan, tobacco and intoxicants; fuel and light; miscellaneous goods and services including non-institutional medical, rents and taxes.

2. 'Last 30 days' and 'Last 365 days': clothing, bedding, footwear, education and medical (institutional) and durable goods.

NSS 55th Consumer Expenditure Survey (1999-2000): For food, pan, and tobacco, each household was asked to report all items over both a 7-day and 30-day recall period. At the same time, the traditional 30-day recall period for durables, clothing, educational and institutional medical expenses was replaced by a 365-day recall only.

1. 'Last $\mathbf{7}$ days' and 'Last $\mathbf{3 0}$ days': food items, pan, tobacco and intoxicants.

2. 'Last 30 days': fuel and light, miscellaneous goods and services including noninstitutional medical, rents and taxes.

3. 'Last 365 days': educational, medical (institutional), clothing, bedding, footwear and durable goods.

Since the data collection methodology in the 55th round was different from those in other rounds of NSS data, there is a problem of deriving compatible estimates across rounds for the purposes of comparison (see Sen and Himanshu, 2004 for details). In calculating the MPCE, the 30-365 day estimates have been used for both rounds.

Firstly, we add up expenditures on 30-day recall basis for food items, pan, tobacco, intoxicants, fuel and light, non-institutional medical, conveyance entertainment, rents and taxes etc. To this we add expenditures on 365-day recall basis for clothing, bedding, footwear, education, institutional medical and durables that have been adjusted for a 
30-day recall period. Monthly per capita expenditure is then derived by dividing this total expenditure on 30-day recall by the household size.

From the two NSS rounds, we obtain MPCE at nominal prices. In order to assess the real changes in MPCE, we use the official poverty lines specified by the Planning Commission as deflators. The poverty lines are stated separately for the rural and urban sectors. In order to derive the combined rural-urban MPCE, the sector-wise deflated MPCE are combined using population weights for rural and urban sectors. 1999-2000 is used as the base year for these calculations. 


\section{Unemployment and Underemployment Rate Cal- culation}

Employment and unemployment are measured using three different approaches, viz. usual status, current weekly status and current daily status. The reference period for these approaches differs - being 365 days preceding the date of survey for 'usual status', 7 days preceding the date of survey for 'current weekly status' and each day of the 7 days preceding the date of survey for 'current daily status'. For this analysis, the unemployment rate is based on the usual status measure and the underemployment rate is based on the current daily status measure.

A person could be in one or a combination of the following three activity or work statuses during a reference period, (i) working or engaged in economic activity; (ii) not engaged in economic activity but either making tangible efforts to seek work or being available for work if the work is available; (iii) not engaged in any economic activity and also not available for work.

(i) and (ii) are associated with 'being in labour force' and (iii) with 'not being in the labour force'. Within the labour force, (i) and (ii) are associated with 'employment' and 'unemployment' respectively.

The usual status refers to:

1. The usual principal activity status (UPS): conditional on being in the labour force, a person is considered employed if he has spent a relatively longer time during the 365 days preceding the date of survey (i.e. major time criterion) engaged in economic activity.

2. Usual principal and subsidiary activity status (UPSS): widens the UPS definition by considering a person as employed if he has pursued some subsidiary economic activity for 30 days or more during 365 days preceding the date of survey.

For this analysis, the unemployment rate is based on the broader UPSS measure. The unemployment rate is calculated as the ratio of the number of people employed to the number of people in the labour force.

Underemployment is commonly defined as the underutilization of labour time of the workers. Some of the persons categorized as usually employed, do not have work throughout the year due to seasonality in work etc. as a result of which their labour time is not fully utilized - they are, therefore, underemployed. We use the current daily status among the usually employed to construct an underemployment measure. 
The current daily activity status for a person is determined on the basis of his activity status on each day of the reference week. Each day of the reference week is comprised of either two 'half days' or a 'full day' for assigning the activity status. For recording time spent on activities pursued by a person in a day, an intensity of 1 is given for an activity that was done for full day and an intensity of 0.5 for the activity that was done for half day. A person is considered employed for the full day if he had worked for 4 hours or more during the day. In this way, a person-day measure can be made wherein a person can be a combination of employed, unemployed or outside of the labour force during the last 7 days. The underemployment rate is defined as the proportion of usually employed who were found to be either unemployed or not in labour force according to the current daily status criteria ${ }^{30}$

\footnotetext{
${ }^{30}$ For more details on calculation of these rates, see Employment and Unemployment Situation in India, NSS 61st round, Report. 515, September 2006.
} 
Centre for Development Economics

Department of Economics, Delhi School of Economics

Delhi 110007 INDIA

Tel.: 27667005/146, 27666703-705, 27666533-535

Fax: 91-11-27667159

Email: office@econdse.org

You can download this and other papers at the CDE Web site:

http://www.cdedse.org 